\title{
Eruption dynamics of the 22-23 April 2015 Calbuco Volcano (Southern Chile): Analyses of tephra fall deposits
}

\author{
J.E. Romero ${ }^{\text {a,* }}$, D. Morgavi ${ }^{\text {b }}$, F. Arzilli ${ }^{\text {c }}$, R. Daga d,e, A. Caselli e,f, F. Reckziegel ${ }^{\text {e,g }}$, J. Viramonte ${ }^{\text {e,g }}$, \\ J. Díaz-Alvarado ${ }^{\mathrm{a}}$, M. Polacci ${ }^{\mathrm{c}}$, M. Burton ${ }^{\mathrm{C}}$, D. Perugini ${ }^{\mathrm{b}}$ \\ a Departamento de Geología, Universidad de Atacama, Av. Copayapu 485, Copiapó, Chile \\ b Department of Physics and Geology, University of Perugia, Piazza dell'Università, 06123 Perugia, Italy \\ c School of Earth, Atmospheric and Environmental Sciences, University of Manchester, M13 9PL Oxford Road, Manchester, United Kingdom \\ ' Laboratorio de Análisis por Activación Neutrónica, Centro Atómico de Bariloche, CNEA, Av. Bustillo km 9.5, 8400 Bariloche, Argentina \\ e Consejo Nacional de Investigaciones Científicas y Técnicas (CONICET), Argentina \\ ${ }^{\mathrm{f}}$ Laboratorio de Estudio y Seguimiento de Volcanes Activos (LESVA), Universidad Nacional de Río Negro, Roca 1242, (8332), Roca, Argentina \\ ${ }^{g}$ INENCO/GEONORTE Univ. Nacional de Salta-CONICET, Av. Bolivia 5150-4400, Salta, Argentina
}

\section{A R T I C L E I N F O}

\section{Article history:}

Received 3 November 2015

Received in revised form 19 February 2016

Accepted 24 February 2016

Available online 27 February 2016

\section{Keywords:}

Calbuco Volcano

Eruption chronology

Tephra stratigraphy

SubPlinian eruption

\begin{abstract}
A B S T R A C T
After 54 years since its last major eruption in 1961, Calbuco Volcano (Ensenada, Southern Chile) reawakened with few hours of warning on 22 April 2015 at 18:05 local time. The main explosive eruption consisted of two eruption pulses (lasting $\sim 1.5$ and $6 \mathrm{~h}$ each one) on 22 and 23 April, producing stratospheric ( $>15 \mathrm{~km} \mathrm{height)}$ eruption columns. The erupted materials correspond to porphyritic basaltic andesite $\left(\sim 55 \mathrm{wt} . \%\right.$ of $\left.\mathrm{SiO}_{2}\right)$. The tephra fall affected mainly the area northeast of the volcano and the finest ash was deposited over Southern Chile and Patagonia Argentina. We studied the tephra fall deposits of both pulses in terms of stratigraphy, distribution, volume, emplacement dynamics and eruption source parameters. Here, we show field observations that have been made 5-470 km downwind and distinguish five layers (Layers A, B, B1, C and D) representing different stages of the eruption evolution: eruption onset (Layer A; pulse 1), followed by the first paroxysmal event (Layer B; pulse 1), in some places interbedded by layer B1, tentatively representing the sedimentation of a secondary plume during the end of pulse 1 . We recognized a second paroxysm (Layer C; pulse 2) followed by the waning of the eruption (Layer D; pulse 2). The total calculated bulk tephra fall deposit volume is $0.27 \pm 0.007 \mathrm{~km}^{3}\left(0.11-0.13 \mathrm{~km}^{3}\right.$ dense rock equivalent), 38\% of which was erupted during the first phase and $62 \%$ during the second pulse. This eruption was a magnitude 4.45 event (VEI 4 eruption) of subPlinian type.
\end{abstract}

(C) 2016 Elsevier B.V. All rights reserved.

\section{Introduction}

Calbuco $\left(41^{\circ} 20^{\prime} \mathrm{S}-72^{\circ} 37^{\prime} \mathrm{W}, 2003 \mathrm{~m}\right.$ a.s.l. $)$ is an active and hazardous stratovolcano in the southern Andes of Chile (Stern et al., 2007), near the city of Ensenada and Puerto Montt (Southern Chile) (Fig. 1A, B). Almost 20 pyroclastic density current (PDCs) and 10 pumice fallouts have been generated by this volcano (Moreno and Naranjo, 2004; Watt et al., 2011) since postglacial times ( $<14 \mathrm{ky})$. Among 13 recognized Holocene $(\sim 10,500$ to $\sim 1100$ years BP) tephra fallout deposits (Table 1), at least two of them were $>5$ in magnitude according to the Pyle (2000) scale, and three of them produced coarse-grained deposits generated by Plinian columns with heights exceeding $20 \mathrm{~km}$ (Watt et al., 2011). Prior to 2015, 11 historical eruptions have been reported since 1792, three of them having a Volcanic Explosivity Index (VEI; Newhall and Self, 1982) $\geq 3$. Commonly, in the previous eruptions, lava flows, tephra fallout, PDCs and lahars characterized Calbuco's activity

\footnotetext{
* Corresponding author.

E-mail address: jorge.romerom@alumnos.uda.cl (J.E. Romero).
}

(Petit-Breuilh, 1999; Moreno et al., 2006; Castruccio et al., 2010). Its last major eruption in 1961 developed a volcanic plume of $\sim 12 \mathrm{~km}$ height and produced $\sim 0.07 \mathrm{~km}^{3}$ dense rock equivalent (DRE) $\left(\sim 0.2 \mathrm{~km}^{3}\right.$ bulk) of tephra (Romero et al., 2013), affecting the northeast sector of the volcano, including the city of Bariloche in Argentina (González-Ferrán, 1995; Petit-Breuilh, 1999, Daga et al., 2014).

In this work, we reports on the stratigraphy, grain size, clast density, total erupted volume, emplacement dynamics and eruption source parameters (ESP) like the column height and eruption duration of the tephra fall deposits associated with the 22-23 April 2015 eruption. We also present a preliminary petrological and geochemical characterization of the erupted rocks.

\section{Calbuco Volcano and the 22-23 April 2015 eruption}

\subsection{Volcanic evolution and historical activity}

Calbuco Volcano (Fig. 1A, B) is an active, truncated-cone composite stratovolcano, covering an area of $150 \mathrm{~km}^{2}$ (Lahsen et al., 1985), 

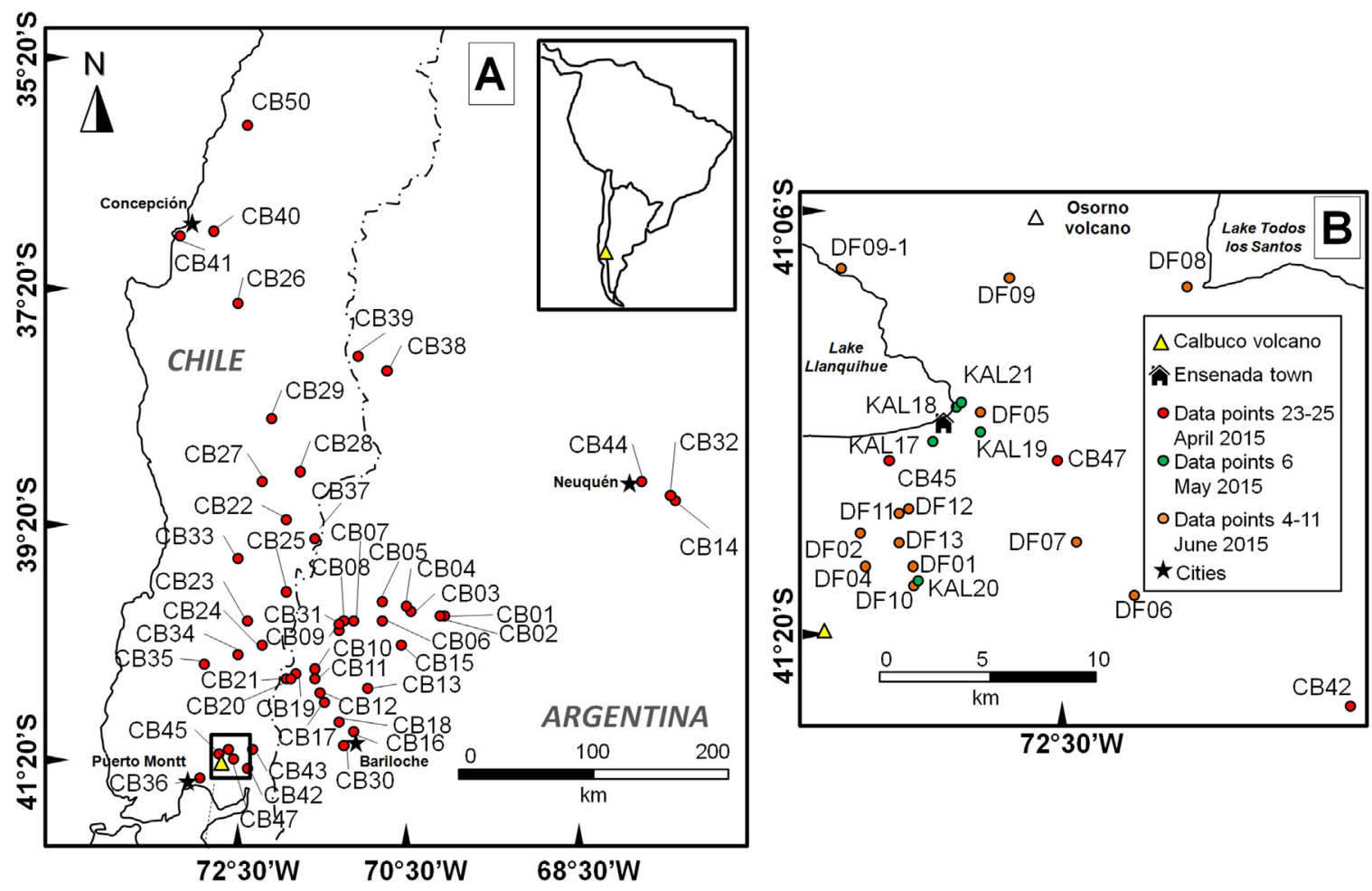

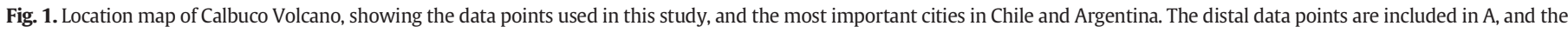
proximal to medial points are in $\mathrm{B}$.

which has been built during the last $~ 300$ ky (Sellés and Moreno, 2011). Its evolution can be divided into four stages; Calbuco 1 (ca. 340-110 ky), which consists of abundant basaltic andesite and minor basaltic and andesitic (50.5-56.6\% $\mathrm{SiO}_{2}$ ) lavas and volcanic breccias (Lahsen et al., 1985; Sellés and Moreno, 2011); Calbuco 2 ( 110$14 \mathrm{ky}$ ), a sequence of glacially-eroded andesitic to dacitic (56-61\% $\mathrm{SiO}_{2}$ ) lavas interbedded with thick breccias from block-and ash-flow and lahars (Sellés and Moreno, 2011). At least two main edifice sector collapses occurred during the Holocene (Clavero et al., 2008). In particular, the $14 \mathrm{ky}$ lateral collapse produced a volcanic avalanche of 2$3 \mathrm{~km}^{3}$ in volume that covered an area of ca. $55 \mathrm{~km}^{2}$ in northnorthwest direction, reaching a maximum thickness of $200 \mathrm{~m}$ and forming an elliptical caldera open toward the north-northeast (Lahsen et al., 1985; Petit-Breuilh and Moreno, 1997; Sellés and Moreno, 2011). During Calbuco 3 (ca. $<14$ ky to Holocene) the activity was located inside the caldera of Calbuco 2, with effusion of andesitic to basaltic andesite $\left(54-60 \% \mathrm{SiO}_{2}\right)$ and dacitic $\left(64.5 \% \mathrm{SiO}_{2}\right)$ lavas, plus PDCs, which were distributed toward the southern and northern sectors of the volcanic edifice (Sellés and Moreno, 2011). The Calbuco 4 (historical eruptions, $<1893 \mathrm{AD}$ ) consists of a series of basaltic andesite to andesitic (54.8-59.3\% $\mathrm{SiO}_{2}$ ) blocky lava flows, a lava dome (growing in 1893, 1911-12 and 1917), block and ash flows, PDCs, tephra falls and lahars (López-Escobar et al., 1995; Sellés and Moreno, 2011). According to Petit-Breuilh (1999), explosive eruptions occurred in 1792, 1845, 1893, 1894-95, 1906-07, 1917, 1927, 1929, 1932, 1945, 1961 and 1972. The highest intensity historical eruption of Calbuco occurred in 1893 and was widely registered in historical accounts (eg. Pöhlmann, 1893; Fisher, 1893; Martin, 1895; González, 1898; Steffen, 1909, 1944; Kinzel and Horn, 1983; Held, 1993), producing tephra fallout, PDCs and hot lahars. Eruption columns reached a maximum height of $12 \mathrm{~km}$ above the crater level (acl) and were emitted on 19 April, 5 September, 5 October and 19 November 1893 (Petit-Breuilh, 1999). Before the 2015 eruption, the previous major eruption occurred $\sim 9$ months after the 1960 M 9.5 Valdivia earthquake (Calbuco is $360 \mathrm{~km}$ distant from the 1960 earthquake epicenter), and lasted 3 months (Klohn, 1963; González-Ferrán, 1995; Petit-Breuilh, 1999).

Table 1

Synthesis of the Holocene tephra fallouts from Calbuco volcano recognized in the Hualaihue region, according to the work of Watt et al. (2011).

\begin{tabular}{|c|c|c|c|c|c|c|c|}
\hline tephra unit & Age year BP & Type & $\mathrm{SiO}_{2} \%$ & Dispersal axis & Volume $\left[\mathrm{km}^{3}\right]$ & Mass x $10^{12}$ & Magnitude \\
\hline Ca13 & $1304-1180$ & Pumice-fall & 57 & SE & 0.5 & 0.4 & $>4.5$ \\
\hline Ca12 & 1919-1654 & Pumice-fall & & ESE & 0.8 & 0.7 & $\leq 5$ \\
\hline Ca11 & $7162-6800$ & Pumice-fall & & SE & 0.9 & 0.7 & $\sim 5$ \\
\hline Ca10 & $8652-6892$ & Pumice-fall & & SE & 0.4 & 0.3 & $>4.5$ \\
\hline $\mathrm{Ca} 9$ & $9285-7214$ & Ash-fall & & & & & \\
\hline $\mathrm{Ca} 8$ & $9529-7881$ & Scoria-fall? & & $\mathrm{E}$ & 1.1 & 0.9 & $>5$ \\
\hline Ca7 & $9745-9452$ & Pumice-fall & 65 & ESE & 0.4 & 0.4 & $>4.5$ \\
\hline $\mathrm{Ca} 6$ & $10,157-9505$ & Pumice-fall & & & & & \\
\hline Ca5 & $10,222-9643$ & Pumice-fall & & & & & \\
\hline $\mathrm{Ca} 4$ & $10,345-9745$ & Pumice-fall & & & & & \\
\hline Ca3 & $10,445-9870$ & Pumice-fall & & & & & \\
\hline $\mathrm{Ca} 2$ & $10,526-10,023$ & Pumice-fall & & & & & \\
\hline Ca1 & $10,571-10,254$ & Pumice-fall & 50 & SE & 1.2 & 1 & $>5$ \\
\hline
\end{tabular}




\subsection{Chronology of the 2015 eruption}

The 2015 eruption chronology is here summarized according to the Servicio Nacional de Geología y Minería (SERNAGEOMIN) reports. From 2010, when the volcano monitoring started at Calbuco, and until 2014 a total of 108 earthquakes occurred, of these 58 were interpreted as volcano-tectonic (VT) events and 50 as long-period (LP) events, and this background level of seismicity was characterized by LP events whose Reduced Displacement (RD) was $<8 \mathrm{~cm}^{2}$ (Valderrama et al., 2015). From 1 January to 21 April 2015147 earthquakes (of these 142 VT) occurred at Calbuco (Valderrama et al., 2015), indicating a notable increase in seismic activity months prior to the eruption. On 22 April at 18:11 GMT (15:11 local time) a seismic swarm of 144 VT and LP events occurred below the east flank of the volcanic edifice (SERNAGEOMIN, 2015a). A thermal anomaly $(<3 \mathrm{~km}$ distance from the crater) was evident on the satellite GOES-13 $3.9 \mu \mathrm{m}$ shortwave IR image at 20:45 GMT (20 min before the eruption onset). The hottest $3.9 \mu \mathrm{m}$ IR brightness temperature at that time was $340.8 \mathrm{~K}$, which is near the saturation temperature of the GOES-13 $3.9 \mu \mathrm{m}$ detectors (CiMMS, 2015). Hybrid seismic events reached RD values of $15.654 \mathrm{~cm}^{2} 10 \mathrm{~min}$ before the eruption onset (Valderrama et al., 2015). After this short-lived precursory activity, a surprisingly intense explosive eruption was observed. The first pulse started at 21:05:55 GMT and lasted as a sustained eruption until 22:32 GMT producing an eruption column of $\sim 15 \mathrm{~km}$ above the crater level (acl) (SERNAGEOMIN, 2015b). After an increase in seismicity at 00.20 GMT, which was characterized by hybrid and tremor signals with respective RD values of $75 \mathrm{~cm}^{2}$ and $500 \mathrm{~cm}^{2}$ (Valderrama et al., 2015), a second and more energetic phase started at 04:08 GMT on 23 April, and developed an eruption column of $>15 \mathrm{~km}$ which was initially dispersed toward the northeast, lasting for $6 \mathrm{~h}$ (SERNAGEOMIN, 2015c). The coldest, cloud-top IR brightness temperatures of both eruption pulses were $-65.0^{\circ} \mathrm{C}$ and $-68.0^{\circ} \mathrm{C}$, and the column was approximately $18-20 \mathrm{~km}$ in height above sea level and 16-18 km acl (CiMMS, 2015). Although no pre-deformation was measured by interferogram up to 1$1 / 2$ days before the eruption, $\mathrm{a} \sim 12 \mathrm{~cm}$ co-eruptive deflation was measured by the Sentinel-1 interferogram on 26 April 2015, corresponding to a volume change of $0.054 \mathrm{~km}^{3}$ about $5 \mathrm{~km}$ southwest of the volcano at a depth of $9.3 \mathrm{~km}$ (Delgado et al., 2015). Discrete ash emissions with columns $<2 \mathrm{~km}$ in height occurred after this last phase on 23 April, including a third pulse which generated a $4 \mathrm{~km}$ high column with dispersion of tephra toward the southeast on 30 April.

\section{Methods}

\subsection{Field mapping and dispersal reconstruction}

The tephra investigation consisted of measuring deposit thickness and maximum clast sizes and sample collection in situ. All the sample sites were studied as soon as possible, between 23 April (after the end of the second phase) and 11 June 2015, in order to avoid surface erosion and reworking of the deposits. Collaboration from the people living in areas affected by ash fallout through the media (facebook, twitter and email) was essential for collecting 26 thickness measurements on 23 April in distal areas of Chile (Fig. 1A). People collected data according to the following instructions: 1) collect samples after the end of ash fall; 2) measure tephra over plane surfaces in protected areas where no possibility of reworking of the deposit occurred; 3) accompany observations with photos containing objects of known dimensions (e.g. coin, pencil) and 4) send georeferenced data. Tephra field surveys were carried out in Chile and Argentina. A total of 21 distal (>27 km downwind) points were collected from 24 to 26 April in the Patagonia Argentina (Fig. 1A), near Piedra del Águila, Junín de los Andes, San Martín de los Andes, Bariloche, Villa la Angostura, and Cardenal Samoré International Pass. Another 18 sites were sampled during two field campaigns on 6 May and from 4 June to 11 June at sites within a distance
$<27 \mathrm{~km}$ from the volcano (Fig. 1A, B). Overall, a total of 65 tephra fallout measurements are presented in this work (Fig. 1A, B). These field data were used to reconstruct the distribution of each recognized tephra fall layer. In addition, the dispersion of ash clouds was described with weather satellite images acquired on 22 and 23 April 2015 by the Geostationary Operational Environmental Satellite (GOES 13; http://cimss. ssec.wisc.edu/goes/blog/archives/date/2015/04/23), with the objective of comparing the deposit distribution with observation of the eruption cloud.

\subsection{Tephra volume calculations}

The deposit distribution was reconstructed using thickness measurements of each tephra layer. The areas of hand-drawn isopachs were measured using GIS software. The integration to compute tephra volume under the isopachs was performed using the Exponential Thinning (Pyle, 1989, 1995), Power Law (Bonadonna and Houghton, 2005) and Weibull models (Bonadonna and Costa, 2012). In the case of the Power Law method, we used as proximal limit of integration $1 \mathrm{~km}$, and distal limits of $30 \mathrm{~km}$ (for units A and D) and $50 \mathrm{~km}$ (for units B and C). In addition, as Bonadonna and Costa (2012) suggested for the Weibull model, we used initial ranges for thickness scale $(\theta)$, characteristic decay length scale of deposit thinning $(\lambda)$ and $n$ (shape parameter, dimensionless) of $0.1-5000 \mathrm{~cm}, 0.1-1000 \mathrm{~km}$ and $0.2-2$, respectively.

\subsection{Tephra characterization}

Tephra fall deposit grain size was characterized using the parameters of Folk and Ward (1957), which were calculated with the Gradisat package (Blott and Pye, 2001). Sieving was performed for three representative samples downwind (DF10, DF05 and DF08) in the range -7.0 to $3.0 \mathrm{phi}(\Phi)$, where $\Phi=-\log _{2} D / D_{0}$, and $D$ is the particle diameter and $D_{0}$ is a reference diameter $(1 \mathrm{~mm})$. The stratigraphic correlation of the tephra layers has been done on the basis of lithology, componentry, grain size and color at most of the proximal to medial sites (5-27 km downwind), and by color changes in distal ( $>27 \mathrm{~km}$ in distance) areas.

The whole rock mineralogical composition was analyzed by X-ray diffraction (XRD), using a PAN analytical X-ray diffractometer (at $40 \mathrm{kV}$ and $45 \mathrm{~mA}$ current), collecting data between 5 and $602 \Theta$ (2Ө is the total change in angle of the incoming electromagnetic wave) (Grupo de Caracterización de Materiales, Centro Atómico Bariloche). For referring to minerals, we used the Whitney and Evans (2010) abbreviations in all the analyses.

Preliminary analyses to determine the juvenile material bulk rock compositions were performed at the School of Earth, Atmospheric and Environmental Sciences of the University of Manchester (Manchester, UK), using the X-Ray fluorescence (XRF) spectrometry technique. The PAN analytical spectrometer, characterized by wavelength dispersive (WDXRF) systems, was used to analyze the bulk composition of the pumices. This instrument works with the Rh anode $\mathrm{x}$-ray tube and it was configured for general geochemical analysis of rocks.

The mineral assemblage and textural features of pumices were observed using an optical microscope.

\subsection{Eruption parameters}

We measured the relative density of 27 clasts (size ranging from 0.7 to $5.3 \mathrm{~cm}$ in diameter) using a laboratory pycnometer filled with distilled water. Isopleth maps were reconstructed measuring the three largest clasts using the geometric mean of their 3 axis, as recommended by Bonadonna et al. (2013). 


\section{Tephra fall deposits of the 22-23 April eruption}

\subsection{Tephra stratigraphy}

A summary of the most representative features (e.g. thickness, largest fragments, componentry and grain size) of the collected samples can be found in Table 2. Five tephra layers have been recognized within the eruptive sequence (Layers A, B, B1, C, and D). Nevertheless, B1 has been observed only in outcrop DF07. In the proximal regime, which extends $<15 \mathrm{~km}$ downwind (Table 2 ), the sequence starts with gray to brown layer A, showing a reverse grading. At site DF-10 (Table 2) layer A consists mostly of low-density, vesicular and light gray to light brown pumice clasts (LDP) ( 80- 90\%), high-density, poorly vesicular gray to brown pumice clasts (HDP) $(\sim 10-\sim 20 \%)$ and rare lithics $(\sim 0.2 \%)$. Both pumice types are coarse lapilli in size. Lithics are not larger than $2 \mathrm{~cm}$ in diameter. The sequence continues with layers B and C, being normally graded and ungraded, respectively. At site DF-10 (Table 2) B and C are composed of brown, coarse lapilli to bomb sized clasts, whose components are in similar proportion as in layer A. Finally, the uppermost layer D is mostly made of HDP ( 90\%), LDP $(\sim 10 \%)$ and rare lithics $(\sim 0.2 \%)$, and has a distinct gray color. The layer is ungraded. A unique outcrop was found ( $13 \mathrm{~km}$ on $62^{\circ}$ azimuth from the vent), which consists of the full eruptive sequence. Here Layer $A$ is characterized by a total thickness of $19 \mathrm{~cm}$, while layer B is interbedded by a high-density pumice layer (B1) of $\sim 0.5 \mathrm{~cm}$ in thickness. No samples were collected from this site due to the difficulty of sampling layer B1 owing its reduced thickness.

The medial-distance (15-27 km from the vent) outcrops are characterized by a stratigraphic sequence formed by coarse ash to fine lapilli comprising layers B, C and D. Here, it is still possible to measure the thickness of each layer, although the full sequence is only $6-13 \mathrm{~cm}$ thick. The representative site DF05 (Table 2) shows an eruptive sequence formed by layers $\mathrm{A}, \mathrm{B}, \mathrm{C}$ and $\mathrm{D}$. In this outcrop the contact between $C$ and $D$ is mostly gradational, and the concentration of HDP particles increases. As observed in other medial sites, this sequence is composed of layers $C$ and D, which is dominated by HDP clasts. The farthest medial-distal outcrop in the downwind direction is represented by DF08 (27 km from the volcano, Table 2). Here, the sequence is composed by coarse ash and layers $\mathrm{B}, \mathrm{C}$ and $\mathrm{D}$ can be distinguished. Their thicknesses are, respectively, $1.5,4.5$ and $\sim 0.5 \mathrm{~cm}$.

At distal sites ( $>27 \mathrm{~km}$ downwind, Fig. $2 \mathrm{~A}$ ) the deposit varies from a single ash layer to a multiple-layered sequence that never exceeds 3 thin layers, which are formed mostly by fine to coarse ash-sized fragments. At some outcrop locations in Argentina, such as Collón
Cura (Fig. 2B), the total deposit is $1.5 \mathrm{~cm}$ thick and is formed by layers $\mathrm{B}, \mathrm{C}$ and $\mathrm{D}$ composed by fine ash. Stratigraphic variability is observed at Ruta 40 (Fig. 2C), Villa La Angostura and Cardenal Samoré international pass (Fig. 2D). Because the total deposit thickness, composed of medium to coarse ash, ranges from 0.4 to $0.5 \mathrm{~cm}$, layers C and D are consistently distinguishable on the basis of change in color, but only in Samoré does the sequence start with layer B (Fig. 2D). As in most of the distal downwind deposits, layer $A$ is not observable. Tephra thinning makes it difficult to measure and sample single ash units. Because of this, only total thickness measurements were performed at these outcrops. In other cases, along the downwind axis in Chile and Argentina, the deposit varies from a millimeter thick to a nominally assigned value of $0.1 \mathrm{~mm}$, to represent trace quantities of ash. The same criterion of $0.1 \mathrm{~mm}$ was used to define trace ash deposition in Watt et al. (2009). At Pucón (Fig. 2E), Riñinahue (Fig. 2F) and Ralún (Fig. 2G) in Chile the deposit varies from 0.1 to $0.4 \mathrm{~cm}$. Even where layers are not distinguishable, the evident difference in the ash color probably indicates that in the Chilean sites only layers B-C were deposited, with the exception of the Ralún site where the gray color suggests the presence of Layer D material. Most distal deposits found at other sites, such as Bariloche (Fig. 2H), Concepción (Fig. 2I) and Neuquén (Fig. 2J), consists of only a thin film whose coverage varied from partial to total, and a maximum thickness of 0.1-1.0 mm was estimated.

The downwind outcrops show a progressive decrease of thickness away from the vent, and the most important feature in the sequence is the disappearance of layer $A$ at a distance of $>26 \mathrm{~km}$ from the vent (Fig. 3A-A'). At Paso Cardenal Samoré (95 km from the vent), layer A is not present, layers $B$ and $C$ are very diffuse and it is not possible to establish a limit between them. These layers are thicker than layer $\mathrm{D}$ whose thickness has decreased considerably $(\sim 1.5 \mathrm{~mm})$ (Fig. 3A-A'). The crosswind pits (Fig. 3B- $\mathrm{B}^{\prime}$ ) are characterized to the northwest by the existence of a thin coarse ash fall, with a thickness of $<1 \mathrm{~cm}$ in DF09-1, which is very diffuse, making difficult a subdivision in additional layers. An evident gray color to the top probably indicates the presence of layer D. The thickness of the deposit rapidly increases up to $13 \mathrm{~cm}$ near the downwind axis, being this sequence formed by layers A, B, C and D (Fig. 3B- $\mathrm{B}^{\prime}$ ). Along the crosswind profile, we found DF07 which yields a total thickness of $19 \mathrm{~cm}$ and shows a full sequence formed by layers A, B, B1, C and D. Here layer B1 appears, but it is not observed in adjacent outcrops such as DF06, which is just $4 \mathrm{~km}$ from DF07 along the crosswind axis (Fig. 3B- $\mathrm{B}^{\prime}$ ). The thickness of the deposit decreases rapidly to $6 \mathrm{~cm}$ in DF06 and layer A disappears. In contrast, layer D is thicker than B and C. Finally, the deposit becomes a single thin $(0.2 \mathrm{~cm})$ layer of ash in CB42, probably associated with layer $\mathrm{D}$, as

Table 2

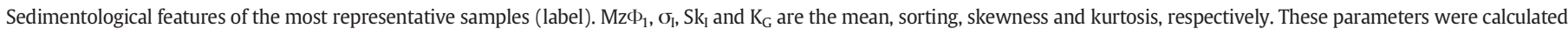
with the Folk and Ward method (1957), using the Gradisat package (Blott and Pye, 2001).

\begin{tabular}{|c|c|c|c|c|c|c|c|c|c|c|c|c|c|}
\hline \multirow[b]{2}{*}{ Label } & \multirow[b]{2}{*}{ Layer } & \multirow[b]{2}{*}{ Thickness [cm] } & \multicolumn{3}{|c|}{ Largest clast [cm] } & \multicolumn{3}{|c|}{ Abundance [\%] } & \multicolumn{4}{|c|}{ Grain size } & \multirow[b]{2}{*}{ Distance [km] } \\
\hline & & & $\operatorname{MLDP}[\mathrm{cm}]$ & $\mathrm{MHDP}[\mathrm{cm}]$ & Lithic $[\mathrm{cm}]$ & LDP & HDP & Lithic & $\mathrm{Mz}_{\Phi 1}$ & $\sigma_{\mathrm{I}}$ & $\mathrm{Sk}_{\mathrm{I}}$ & $\mathrm{K}_{\mathrm{G}}$ & \\
\hline DF-02 & A & 4 & 2.9 & 2.9 & 1.3 & $\sim 90$ & $\sim 10$ & $\sim 0.2$ & & & & & 7 \\
\hline DF-02 & B & 7 & & & & & & & & & & & 7 \\
\hline DF-02 & $\mathrm{C}$ & 5 & 6.8 & 2.8 & 2 & $\sim 70$ & $\sim 30$ & $\sim 0.2$ & & & & & 7 \\
\hline DF-02 & $\mathrm{D}$ & 2 & 3.8 & 4.8 & 2.8 & $\sim 30$ & $\sim 70$ & $\sim 0.2$ & & & & & 7 \\
\hline DF-05 & A & 2 & 1 & 1.3 & & $\sim 80$ & $\sim 20$ & $\sim 0.2$ & -1.414 & 1.124 & -0.177 & 0.949 & 15 \\
\hline DF-05 & $\mathrm{BC}$ & 3 & & & & & & & -1424 & 1.199 & & & 15 \\
\hline DF-05 & & 6 & 2.4 & 1.2 & & $\sim 80$ & $\sim 20$ & $\sim 0.2$ & -1.424 & 1.199 & -0.209 & 0.907 & 15 \\
\hline DF-05 & $\mathrm{D}$ & 2 & & & & & & & -0.880 & 0.854 & -0.252 & 1.008 & 15 \\
\hline DF-10 & A & 10 & 3.5 & 2.5 & 2 & $\sim 90$ & $\sim 10$ & $\sim 0.2$ & -3.079 & 1.068 & 0.125 & 0.899 & 5 \\
\hline DF-10 & B & 14 & & & & & & & -3.662 & 1.478 & 0.458 & 0.860 & 5 \\
\hline DF-10 & $\mathrm{C}$ & 25 & 7.2 & 4.1 & 2.5 & $\sim 90$ & $\sim 10$ & $\sim 0.2$ & -2.514 & 1.201 & 0.075 & 0.958 & 5 \\
\hline DF-10 & $\mathrm{D}$ & 8 & 2.9 & 3.3 & 1.7 & $\sim 10$ & $\sim 90$ & $\sim 0.2$ & -2.844 & 1.454 & 0.359 & 1.841 & 5 \\
\hline KAL-18 & $\mathrm{AB}$ & 8.5 & 1 & & & & & & -0.543 & 0.790 & -0.078 & 0.926 & 16 \\
\hline KAL-18 & $\mathrm{CD}$ & 9.7 & 0.6 & & 0.4 & & & & -0.864 & 0.824 & 0.243 & 0.819 & 16 \\
\hline KAL-21 & $\mathrm{AB}$ & 13 & 1.5 & & & & & & -0.518 & 0.788 & -0.076 & 0.972 & 15 \\
\hline KAL-21 & $\mathrm{CD}$ & 3 & 0.8 & & 0.7 & & & & -0.591 & 0.791 & -0.074 & 0.852 & 15 \\
\hline DF-08 & $\mathrm{BC}$ & 1.5 & & & & & & & 0.813 & 0.630 & -0.040 & 0.906 & 27 \\
\hline DF-08 & $\mathrm{D}$ & 4.5 & & & & & & & 0.939 & 0.490 & 0.035 & 0.994 & 27 \\
\hline
\end{tabular}



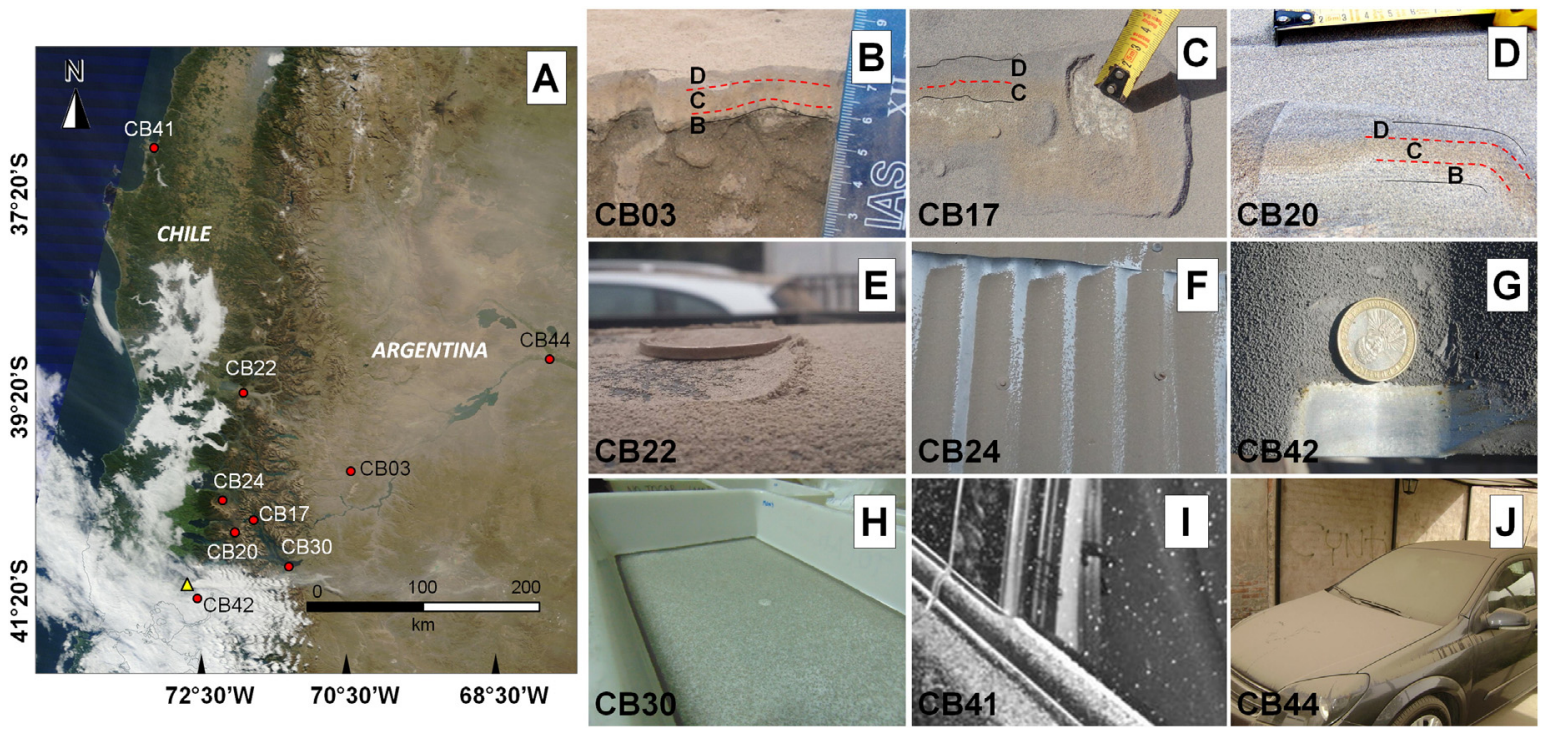

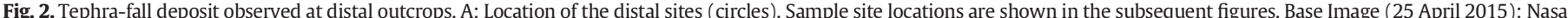

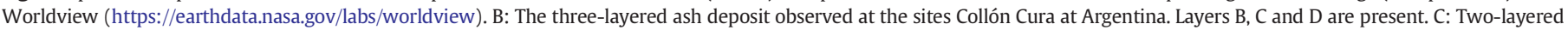

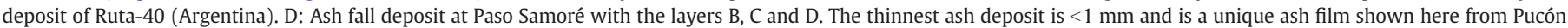
(E), Riñinahue (F), Ralún $(G)$, Bariloche $(H)$, Concepción (I) and Neuquén (J).
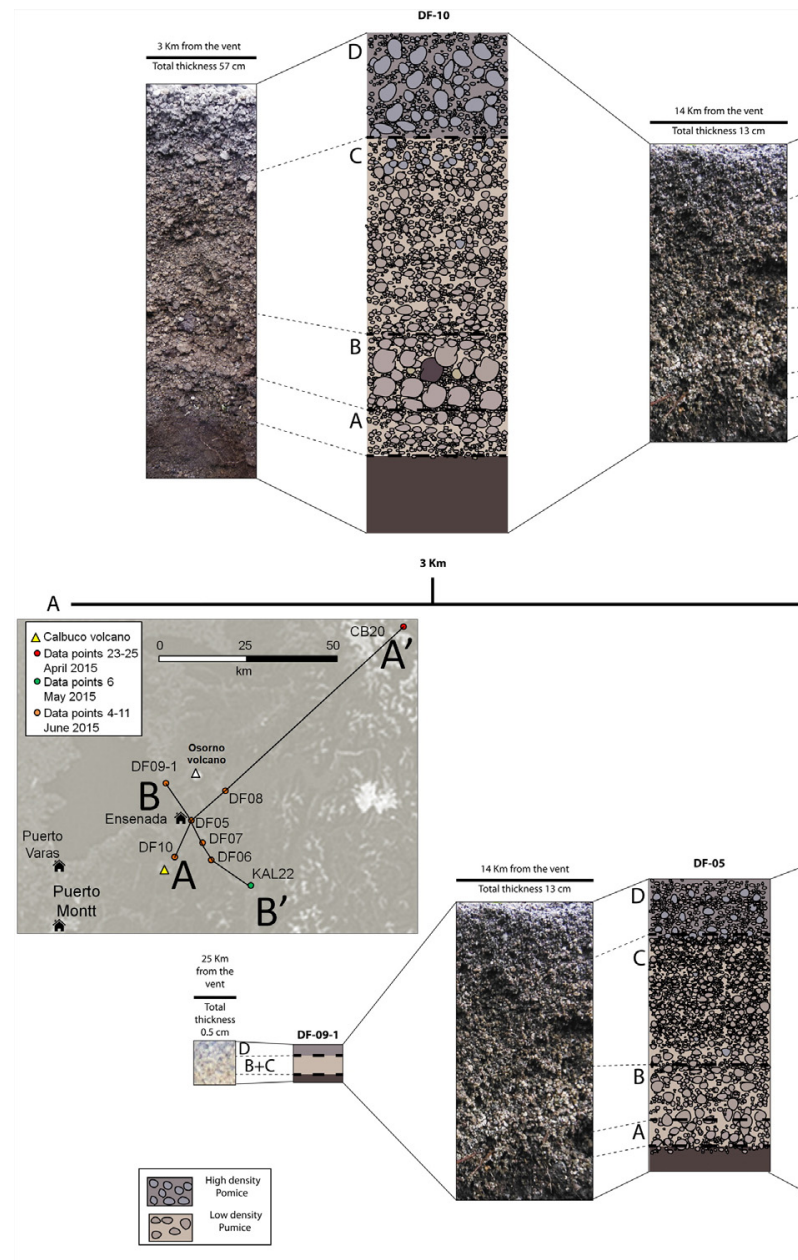

$25 \mathrm{~km}$
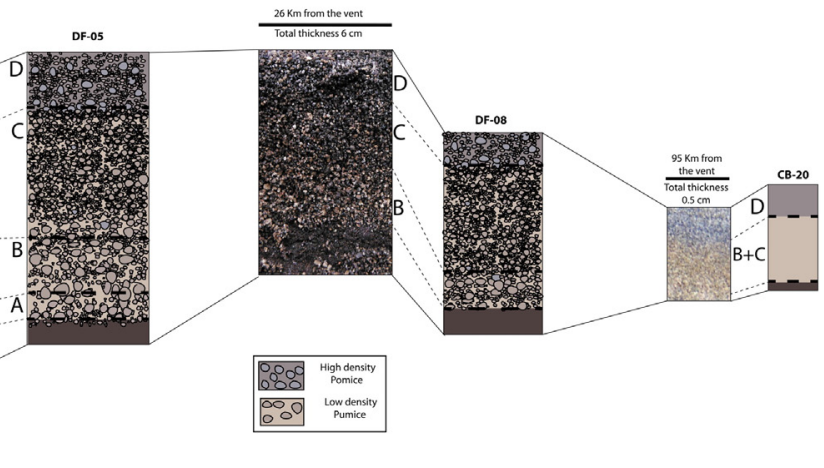

$13 \mathrm{Km}$

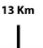

$26 \mathrm{Km}$

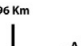



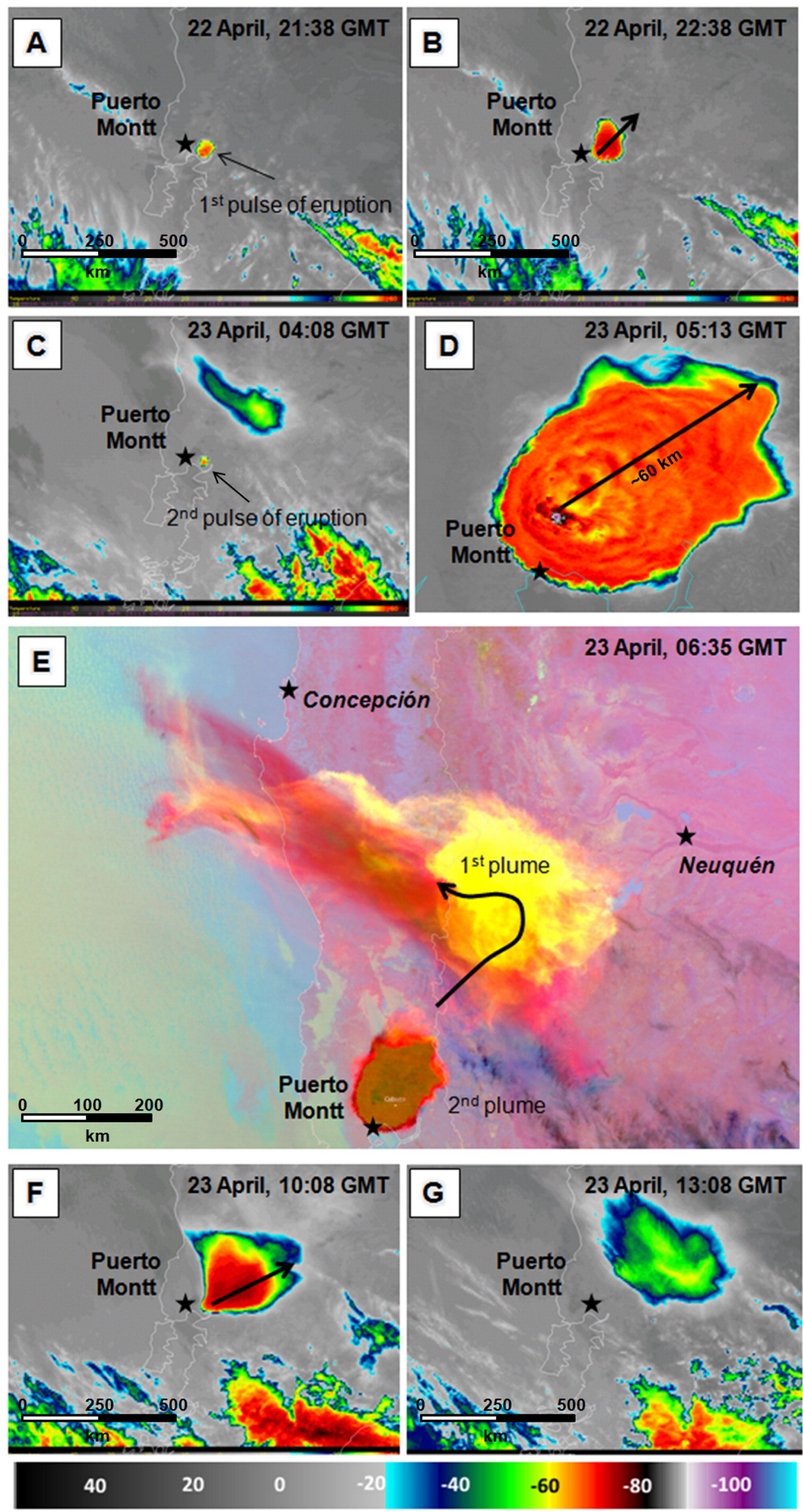
indicated by its grayish color. This suggests that the dispersion of $D$ was mostly to the east rather than northeast, which is the case of layers A, B and $\mathrm{C}$.

\subsection{Tephra dispersal, distribution and volumes of tephra deposits}

The plume image was captured by satellite GOES-13 on 22 April at 21.38 GMT just 33 min after the start of the eruption (Fig. 4A). The satellite image shows the expansion of the cloud toward the northeast on an azimuth of $48^{\circ}$ (Fig. 4B). The plume detached from the source at 23.08 GMT, indicating the end of the first phase of the eruption, and then dispersed over Argentina. After a period of rest between 22.33 and 04.00 GMT, a second plume started growing at 04.08 GMT (Fig. 4C) on 23 April and dispersed on an azimuth of $\sim 55^{\circ}$ (Fig. 4D). At 06.35 GMT both the first and second plume coexisted between approximately $37^{\circ} \mathrm{S}$ and $41^{\circ} \mathrm{S}$, due to a change in wind direction that caused the rotation of the first plume, dispersing the floating ash toward the northwest over southern Chile and western Argentina (Fig. 4E). The second plume became more elongated near the source at 09.38 GMT (Fig. 4F), probably due to a drastic decrease in the intensity and a minor change in the dispersal direction to azimuth $\sim 67^{\circ}$. This plume left the source at 10.08 GMT on 23 April, being dispersed over Chile and Argentina. The cloud persisted over the region $37^{\circ} \mathrm{S}$ to $39^{\circ} \mathrm{S}$ between 11.45 and 16.00 GMT (Fig. 4G), as observed with the first plume (Fig. 4E).

The distal deposit distribution has been reconstructed for the total stratigraphic sequence using 47 field measurements taken in Chile and Argentina (Fig. 5A). The ash fall limit (0.01 cm thickness) has been hand-drawn using 12 measurements in Chile and Argentina. In that context, the southeastern limit of this finest ash was not measured in the field; rather it has been extrapolated by using satellite images acquired on 25 April (Fig. 5A). In comparison, with a total of 19 measurements we reconstructed the isopach maps by hand-drawning for the total deposit in the proximal to medial area (Fig. 5B), and for individual layers A, B, C and D (Fig. 5C-G). Due to paucity of field data, we did not reconstruct an isopach map for layer B1. The deposit thins with distance with exception of an outsider region near Piedra del Aguila and Collón Cura river, both in Argentina (represented by CB03 and $\mathrm{CB06}$, respectively in Fig. 5A), which represents a secondary thicker region (Fig. 5A). The non elliptical shape of the total deposit at distal locations (Fig. 5A), and also the secondary thicker region could be related to the plume complex dispersal during the eruption (Fig. 5E, G) and it is discussed in Section 5.

Isopach maps of individual layers (Figs. 5C-6F) show that, during the first phase of activity, layer $A$ is aligned on an azimuth of $\sim 47^{\circ}$ and is not identified at a distance beyond $15 \mathrm{~km}$ from the vent (Fig. 5C). Layer B has an elliptical deposition pattern along an azimuth of $\sim 42^{\circ}$ and extends considerably further than layer A (Fig. 5D, E). The distribution of layers A and B are in good agreement with the plume dispersion during the first pulse of eruption, suggesting that both layers were formed during that stage. Layer $\mathrm{C}$ has an elliptical shape with dispersal axis of azimuth $\sim 50^{\circ}$ (Fig. 5E), which is similar to the plume axis observed during the start of the second pulse of the eruption. Layer $\mathrm{C}$ thins from $25 \mathrm{~cm}$ to $\sim 3 \mathrm{~cm}$ over a distance of $27 \mathrm{~km}$ downwind. Finally, layer $\mathrm{D}$ thins gradually along its axis toward the east ( $71^{\circ}$ azimuth) and is more elongate relative to layers B and C (Fig. 5E, F).

We calculated tephra volumes (Table 3 ) using the thinner isopach mapped of each layer, which is $2 \mathrm{~cm}$ in the case of layers A, B and D, and $3 \mathrm{~cm}$ for layer $\mathrm{C}$. Because no data have been obtained for individual layers in distal regions, we assume that the integrated volumes only reflect proximal and medial thinning trends of these deposits. The range of volume estimates, obtained from the Exponential (Pyle, 1989, 1995), Power-Law (Bonadonna and Houghton, 2005) and Weibull techniques (Bonadonna and Costa, 2012), measured in units of $10^{-3} \mathrm{~km}^{3}$ for each layer are: A) 8.61-21.6; B) 30.9-34.0; C) 50.3-64.3; D) 9.6-37.1. The considerable variability of results of the Weibull method, specially for calculations of layers A and D, can be attributed to the lack of distal data, which may result in a discrepancy of $99 \%$ (Bonadonna and Costa, 2012). The sum of integrated individual volumes for each layer, using the different methods (Table 3), for proximal and medial data, yields a bulk volume that ranges from 0.105 to $0.14 \mathrm{~km}^{3}$. If the same methods are applied for the total deposit thickness data in all locations (including distal, $>27 \mathrm{~km}$ downwind from the vent), we estimate the bulk volume (Table 3) to range from 0.267 to $0.277 \mathrm{~km}^{3}$. Using a bulk deposit density, measured from four fine-grained lapilli samples, of $\sim 997.3 \mathrm{~kg} \mathrm{~m}^{-3}$, we estimated the deposit mass to be $2.66-2.76 \times 10^{11} \mathrm{~kg}$. Assuming a proportion of $80 \%$ LDP and $20 \%$ HDP, with density of $2450-2500 \mathrm{~kg} \mathrm{~m}^{-3}$ for a basaltic andesitic magma, we calculate a deposit dense rock equivalent (DRE) of $\sim 0.11-0.13 \mathrm{~km}^{3}$.

\subsection{Physical features of ejected material}

\subsubsection{Grain-size}

At the most proximal outcrop DF10 the basal layer A shows a polymodal (Fig. 6A) and poorly sorted distribution of coarse lapilli particles. Three modes are identified: $-4.0,-2.9$ and -2.13 Ф. As observed in other eruptions, the existence of several modes for the grain size distribution of the tephra deposits at a few kilometers from the vent is due to pronounced differences in density between pumice, crystals, and rock fragments (Fisher and Schmincke, 1984). Layers B-C are composed of coarse lapilli and some bomb-sized fragments, forming poorly sorted distributions with notable modes at -4.3 and $-2.6 \Phi$, respectively. Layer D has finer grains with modes at $-2.9,-2.13$ and $2.0 \Phi$.

In the medial distance site DF05 the grain size is smaller than at DF10 (Fig. 6B). Layers A and B-C are polymodal and poorly sorted, while layer D is polymodal and moderately sorted; A, B-C and D modes are at $-2.13,-1.38$ and $-0.13 \Phi$.

Site DF08, which marks the limit between the medial-distal outcrops, includes layers B-C and D, which were sieved at 0.24 Ф steps (Fig. 6C); they present well sorted unimodal distributions with a single mode at $0.75 \Phi$. Distal and very distal samples were not sieved by layer, because of their limited thickness did not allow us to perform a sampling. Meanwhile, a laser grain size analysis ( $<63 \mu \mathrm{m}$ fraction) of the whole deposit collected at CB30 (Bariloche, Argentina) shows a unimodal, very well sorted and almost normal distribution with a mode at $-4.8 \Phi$ (Romina Daga, personal communication).

A reverse size grading is common in layer A; in contrast, layers B and $C$ represent the thickest part of the profile and are very uniform in componentry, grain size distribution, and the presence of normal grading. No grading is observed in layer $\mathrm{D}$.

\subsubsection{Tephra petrography and mineralogy}

The eruption produced two types of pumice clasts: HDP is poorly vesiculated and crystal-rich (up to $40 \%$ crystals by volume), whereas LDP is characterized by lower crystallinity due to the higher vesicle volume fraction. Banded pumice clasts are quite common in layers A, B and C, and their bands consist of both high-density and low-density pumice. Denser pumice clasts are most common in layer D. The presence of bands is related to areas with different vesicle volume fractions within the pumice. Textural features and mineralogical assemblages of dense (Fig. 7A and B) and vesiculated (Fig. 7C and D) pumices are constant

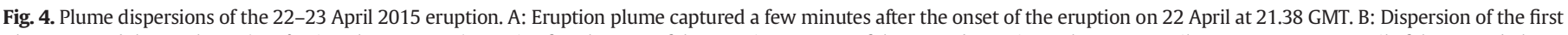

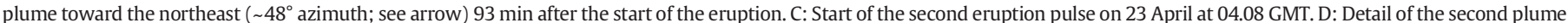

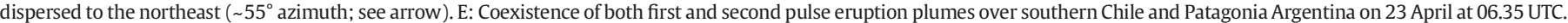

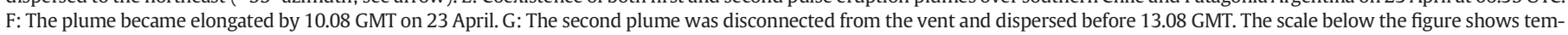
perature in ${ }^{\circ} \mathrm{C}$. The Figures A, B, C, E, F and G are courtesy of the GOES-13 (Goes-East); D is from the VIIRS-I-band 5 (NOAA/NASA RAMMB/CIRA). Black stars represent capital cities. 

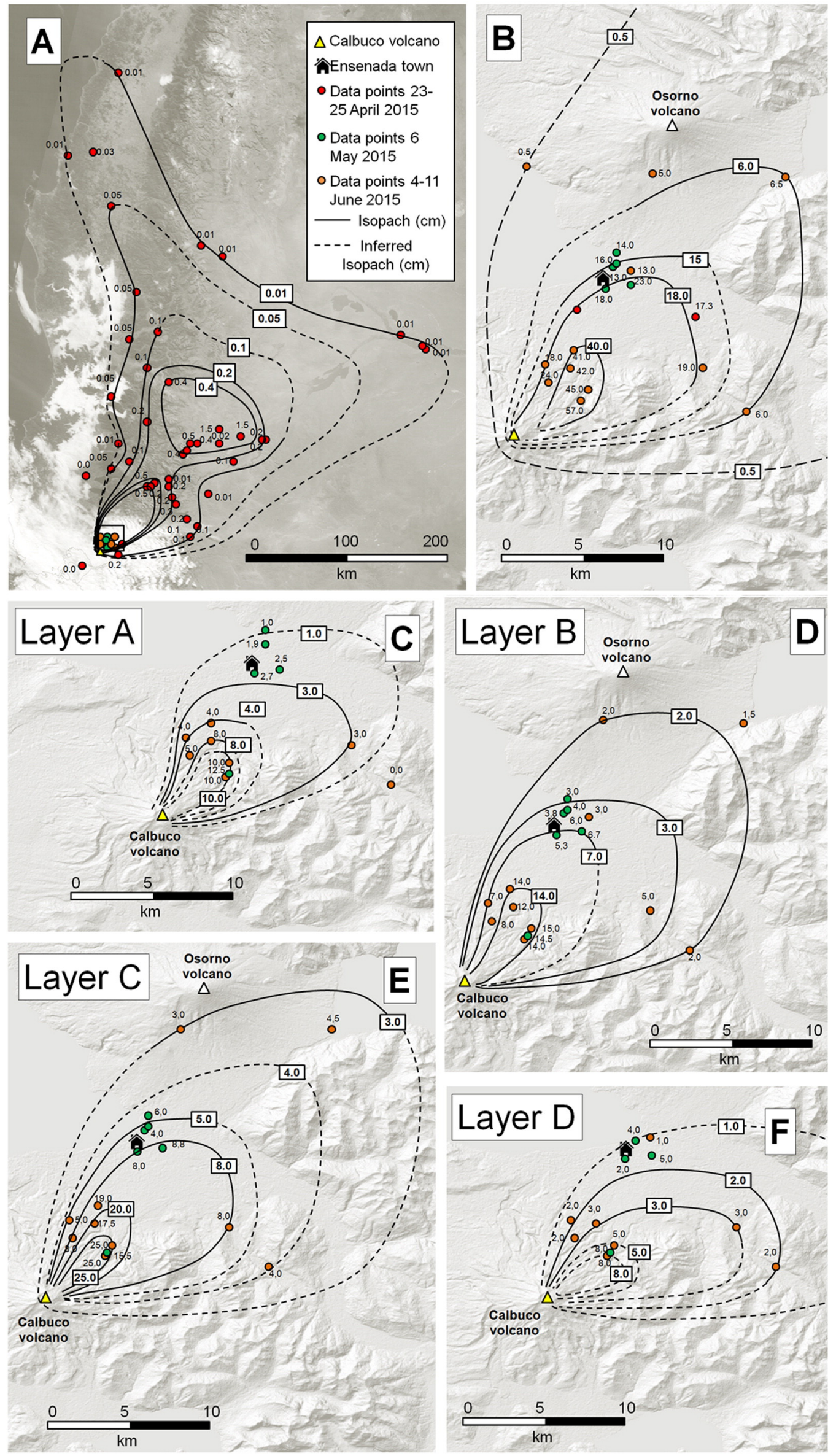
for each layer. From a petrographic point of view, pumice clasts are characterized by porphyritic textures with no evidence of anisotropy: in fact, crystals and vesicles are not preferentially oriented with respect to a possible magma flow direction (Fig. 7). Crystal textures include phenocrysts in a glassy groundmass with a minor presence of microlites. The mineralogical assemblage of pumice consists of plagioclase (plg), orthopyroxene (opx), clinopyroxene (cpx) and Ti-magnetite (ox) (quartz is present as accessory phase). The size of these mineral grains ranges between $\sim 100 \mu \mathrm{m}$ and $\sim 1 \mathrm{~mm}$, but microlites of a few microns (from $<1$ to $30 \mu \mathrm{m}$ ) are also present in the glassy matrix, and their assemblage consists of plg, opx, cpx and ox. Occasionally, a glomeroporphyritic texture is observed, with aggregates consisting of plg, cpx and opx (Fig. 7B and C). Normal zonation in plg phenocrysts is also observed. Preliminary XRF analyses show that the bulk compositions of these samples correspond to porphyritic basaltic andesites $\left(\sim 55 \mathrm{wt} . \%\right.$ of $\left.\mathrm{SiO}_{2}\right)$. The groundmass composition of these samples has not been analyzed in details yet, however, the first results indicate that it is a dacite ( $66 \mathrm{wt} . \%$ of $\mathrm{SiO}_{2}$; Astudillo et al., 2015).

An ash sample suite collected at San Carlos de Bariloche, Argentina (100 km E from Calbuco) around 10:30 GMT on 23 April, was analyzed using XRD (see Methods). This sample contains material emitted during the two main pulses, because their deposition occurred during the night of 22 April and early morning of 23 April, resulting in a millimeter-thick deposit. At that time, the sky was cloudy and only very fine 'dust' was perceptible in the atmosphere, producing an ash trace over the trays. This fine-ash sample contains abundant crystal fragments and lithic clasts, and a low amount of volcanic glass. Main accessory phases include plg, opx and cpx. The glassy material occurred as vesicular and blocky particles in the coarse fraction $(\sim 200 \mu \mathrm{m})$ and as angular, dense shards in the fine fraction.

Observations of the $<63 \mu \mathrm{m}$ fraction of the proximal-medial KAL-18 and KAL-21 samples for layer B (Table 2), indicate that the ash is gray and composed by vitreous and crystalline fragments. Vitreous fragments are mainly blocky, angular and compact glass shards, and occasionally exhibit starry bubble walls. Free crystals are angular to sub-rounded, with abundant plg, px and a minor quantity of quartz. Within the same sample but in layer $C$, the $<63 \mu \mathrm{m}$ fraction contains more free crystals relative to layer $\mathrm{B}$; the mineral assemblage is similar. In addition, the ash of layer $\mathrm{C}$ is clear brown.

\subsection{Eruption parameters}

In addition to crystallinity and vesicularity, which have allowed us to discriminate well between the two types of pumice (LDP and HDP), measurement of clast densities has confirmed the bimodality of juvenile particles. The analyzed fragments consisted of 14 LDP, 9 HDP and 4 lithic samples. The average density of LDP, HDP and lithic clasts has been calculated as $760 \pm 0.23,1670 \pm 0.25$ and $2190 \pm 0.39 \mathrm{~kg} \mathrm{~m}^{-3}$, respectively. The LDP and HDP clasts differ at least in the amount of vesicles, as observed in the samples. In contrast, lithics have uniform density and vesicularity is low.

We measured the three largest (or maximum size) clasts of layers A, B-C and D: 8 maximum LDP (MLDP), 8 maximum HDP (MHDP) and 6 maximum lithics (ML). With clast density data, we applied the model of Carey and Sparks (1986) to estimate the plume height above the vent in $\mathrm{km}$ (Table 4). Computed column heights are considerably smaller (9.0-14.5 km) when a density of $760 \mathrm{~kg} \mathrm{~m}^{-3}$ is used (MLDP), in contrast to the results obtained using denser clasts (MHDP and $\mathrm{ML}$ ), which give higher values (12 to $15.4 \mathrm{~km}$ height). Bonadonna et al. (2013) suggest that pumices are not recommended for this procedure, because these fragile fragments can be broken during the impact with soil. For this reason, we prefer the results calculated with MHDP
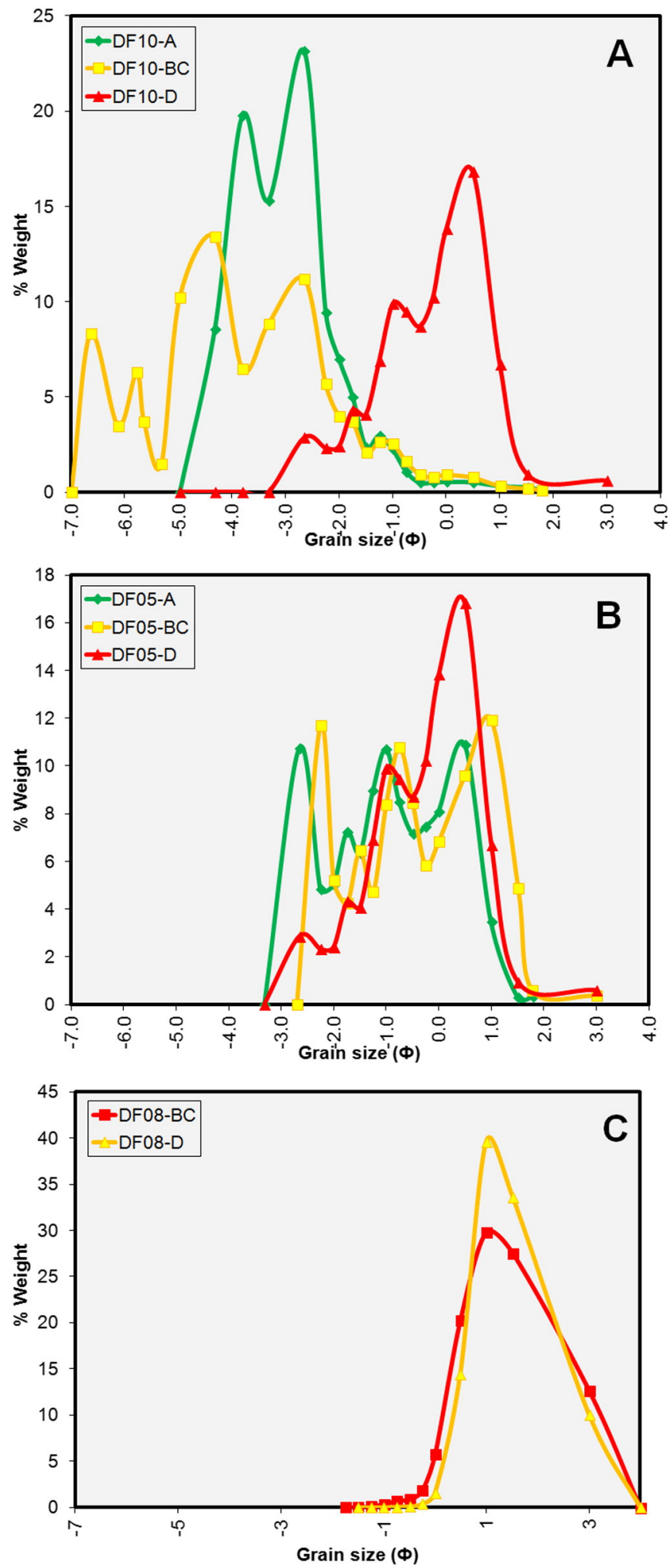

Fig. 6. Grain size distribution for proximal (A), medial (B) and medial-distal (C) samples of tephra collected along the dispersal axis. Sample labels can be found in Table 3 .

and ML fragments ( 1670 or $2190 \mathrm{~kg} \mathrm{~m}^{-3}$ ). Using the method of Carey and Sparks (1986) and assuming a density of $1670 \mathrm{~kg} \mathrm{~m}^{-3}$, we calculated the MHDP of $2.4 \mathrm{~cm}$ diameter for layers B-C. The inferred isopleth of the

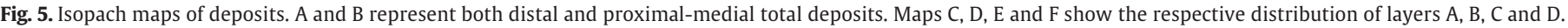

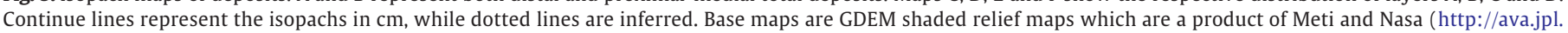
nasa.gov/gdem.php?id=1508-02=). 
Table 3

Volume calculations for each layer as calculated using different models.

\begin{tabular}{|c|c|c|c|c|c|c|}
\hline \multirow[b]{2}{*}{ Unit } & \multicolumn{5}{|c|}{ Proximal-medial regime } & \multirow{2}{*}{$\begin{array}{l}\text { Proximal-distal } \\
\text { Whole deposit }(A+B+C+D)\end{array}$} \\
\hline & $A$ & $\mathrm{~B}$ & $\mathrm{C}$ & $\mathrm{D}$ & Whole deposit $(A+B+C+D)$ & \\
\hline \multicolumn{7}{|l|}{ Erupted volume $\left(\mathrm{km}^{3}\right)$} \\
\hline Exponential thinning* & $8.61 \mathrm{E}-03$ & 3.40E-02 & 5.03E-02 & $1.24 \mathrm{E}-02$ & 1.05E-01 & 2.70E-01 \\
\hline Number of isopachs & 4 & 5 & 5 & 4 & 5 & 10 \\
\hline Mean rel. squared error & & $1.07 \mathrm{E}-01$ & $9.44 \mathrm{E}-02$ & $5.30 \mathrm{E}-31$ & $6.72 \mathrm{E}-02$ & 0.085 \\
\hline Segment 1 & $5.24 \mathrm{E}-03$ & $1.53 \mathrm{E}-02$ & $1.30 \mathrm{E}-02$ & $2.39 \mathrm{E}-03$ & & $6.74 \mathrm{E}-02$ \\
\hline c & 0.23 & 0.22 & 0.31 & 2.42 & & 0.8577 \\
\hline$m$ & 0.25 & 0.14 & 0.07 & 1.37 & & 0.1524 \\
\hline Segment 2 & 3.37E-03 & 1.87E-02 & $3.74 \mathrm{E}-02$ & $9.96 \mathrm{E}-03$ & & $2.03 \mathrm{E}-01$ \\
\hline$c$ & 0.1223 & 0.06 & 0.169 & 0.04691 & & 0.02136 \\
\hline$m$ & 0.1829 & 0.07 & 0.0877 & 0.09531 & & 0.01411 \\
\hline Power law** & $1.12 \mathrm{E}-02$ & 3.32E-02 & 6.43E-02 & $1.00 \mathrm{E}-02$ & 1.19E-01 & 2.77E-01 \\
\hline Number of isopachs & 4 & 5 & 5 & 4 & 5 & 10 \\
\hline Mean rel. Squared error & $3.17 \mathrm{E}-02$ & 4.42E-02 & $5.41 \mathrm{E}-02$ & $2.23 \mathrm{E}-02$ & $3.81 \mathrm{E}-02$ & $8.08 \mathrm{E}-02$ \\
\hline PL-coefficient $\left(\mathrm{T}_{\mathrm{PL}}\right)$ & 0.66 & 0.82 & 1.08 & 0.16 & & 7.65 \\
\hline PL-exponent (m) & 1.529 & 1.31 & 1.17 & 0.99 & & 1.70 \\
\hline Proximal limit & 1 & 1 & 1 & 1 & & 1 \\
\hline Distal limit & 30 & 50 & 50 & 30 & & 450 \\
\hline Weibull method ${ }^{* * *}$ & $2.16 \mathrm{E}-02$ & 3.09E-02 & 5.09E-02 & $3.71 \mathrm{E}-02$ & 1.40E-01 & 2.67E-01 \\
\hline Number of isopachs & 4 & 5 & 5 & 4 & 5 & 10 \\
\hline Mean rel. squared error & 3.07E-03 & 3.84E-02 & $3.14 \mathrm{E}-02$ & $1.98 \mathrm{E}-02$ & 2.32E-02 & 0.10 \\
\hline$\theta$ & 0.04781 & 0.02025 & 0.05634 & 0.0002 & & 0.01 \\
\hline$\lambda$ & 38.80 & 25.85 & 23.44 & 974.2 & & 99.97 \\
\hline$n$ & 0.67 & 0.94 & 1.22 & 1.04 & & 0.90 \\
\hline \multicolumn{7}{|l|}{ Erupted mass ( $\mathrm{kg}$ ) } \\
\hline Exponential derived & $6.32 \mathrm{E}+09$ & $2.50 \mathrm{E}+10$ & $2.69 \mathrm{E}+10$ & $6.61 \mathrm{E}+09$ & $1.05 E+11$ & $2.69 \mathrm{E}+11$ \\
\hline Power law derived & $8.20 \mathrm{E}+09$ & $2.44 \mathrm{E}+10$ & $3.44 \mathrm{E}+10$ & $5.35 \mathrm{E}+09$ & $1.18 \mathrm{E}+11$ & $2.76 E+11$ \\
\hline Weibull derived & $1.58 \mathrm{E}+10$ & $2.20 \mathrm{E}+10$ & $2.64 \mathrm{E}+10$ & $2.09 \mathrm{E}+10$ & $1.40 \mathrm{E}+11$ & $2.66 E+11$ \\
\hline
\end{tabular}

Bold-type represent final values for volume and mass of the tephra fallout deposits.

* Calculated through the combination of the volumes calculated for the Segments 1 and 2, following the method of Pyle (1989): $T(x)=T_{0} e^{-k A^{0.5}}$.

** Calculated following the approach of Bonadonna and Houghton (2005). $\mathrm{T}_{\mathrm{PL}}$ and $m$ are the coefficient and exponent of the power law. Here, we used both proximal (C) and distal (B) limits of

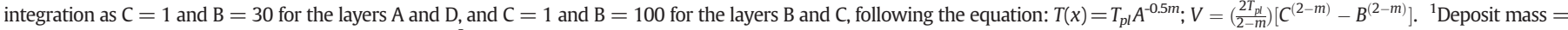
volume $*$ density. We have used a density of $760 \mathrm{~kg} / \mathrm{m}^{3}$ (deposit density).

*** Calculated as used in the Weibull function integration (Bonadonna and Costa, 2012). $V=2\left(\frac{\theta \lambda^{2}}{n}\right)$. Initial ranges for $\theta, \lambda, n$ are $0.1-5000 \mathrm{~cm}, 0.1-1000 \mathrm{~km}$ and $0.2-2$, respectively.
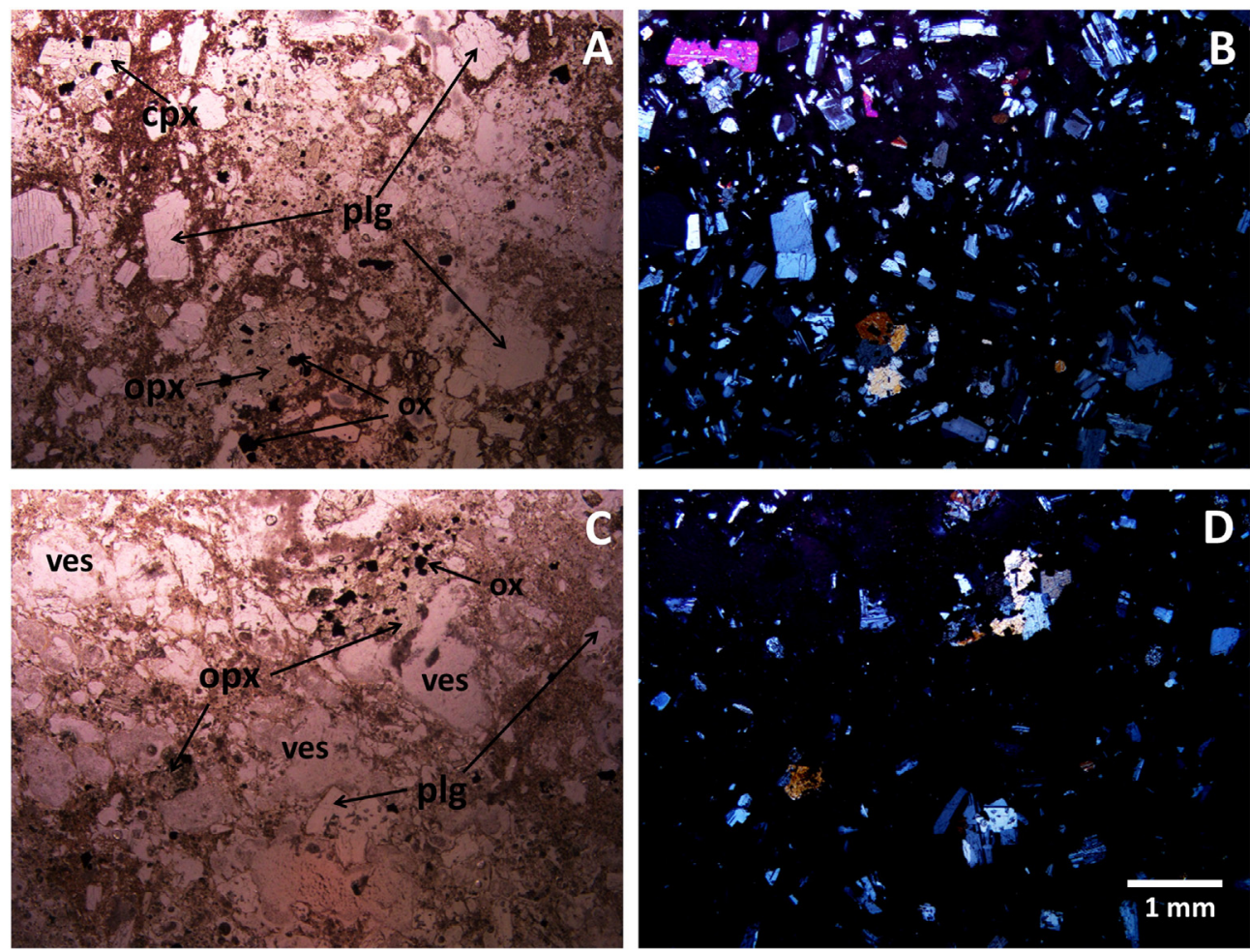

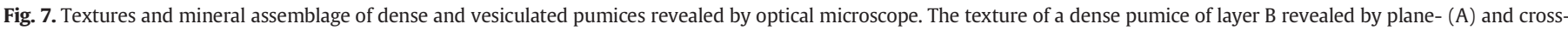

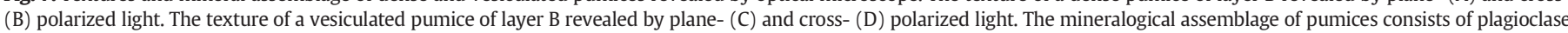
(plg), orthopyroxene (opx), clinopyroxene (cpx) and Ti-magnetite (ox). 
Table 4

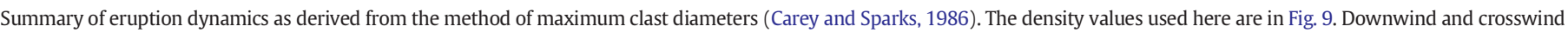

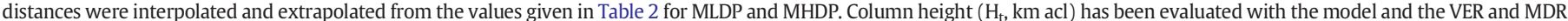

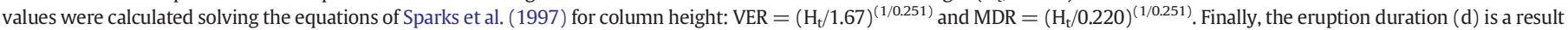

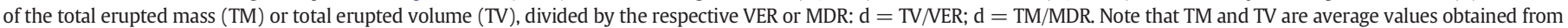
Table 3. The bold-type values are considered as the most realistic when compared with the direct and satellite observations of the eruption evolution.

\begin{tabular}{|c|c|c|c|c|c|c|c|c|}
\hline Unit & Density $\left(\mathrm{kg} / \mathrm{m}^{3}\right)$ & Diameter $[\mathrm{cm}]$ & Downwind [km] & Crosswind [km] & $\mathrm{H}_{\mathrm{t}}[\mathrm{km}] \mathrm{acl}$ & $\operatorname{VER}\left[\mathrm{m}^{3} / \mathrm{s}\right]$ & MDR [kg/s] & Duration [h] \\
\hline A & 760 & 2.62 & 9.01 & 3.33 & 9.3 & $7.58 \mathrm{E}+02$ & $1.90 \mathrm{E}+06$ & 1.48 \\
\hline A & 1670 & 2.4 & 8.15 & 2.37 & 12.09 & $2.09 \mathrm{E}+03$ & $5.23 E+06$ & 0.54 \\
\hline A & 2190 & 2.4 & 4.75 & 1.76 & 10.23 & $1.09 E+03$ & $2.74 \mathrm{E}+06$ & 1.03 \\
\hline $\mathrm{B}-\mathrm{C}$ & 760 & 5.26 & 8.78 & 3.2 & 14.5 & $4.21 \mathrm{E}+03$ & $1.05 \mathrm{E}+07$ & 5.86 \\
\hline B-C & 1670 & 2.4 & 10.31 & 3.52 & 15.38 & $5.28 \mathrm{E}+03$ & $1.32 E+07$ & 4.67 \\
\hline $\mathrm{B}-\mathrm{C}$ & 2190 & 1.83 & 9.3 & 3.2 & 14.5 & $4.21 \mathrm{E}+03$ & $1.05 \mathrm{E}+07$ & 5.86 \\
\hline $\mathrm{D}$ & 760 & 2.62 & 9.5 & 3.15 & 9.05 & $6.82 \mathrm{E}+02$ & $1.71 \mathrm{E}+06$ & 7.64 \\
\hline D & 1670 & 4.84 & 6.36 & 1.7 & 11.78 & $1.89 \mathrm{E}+03$ & $4.73 E+06$ & 2.76 \\
\hline D & 2190 & 1.83 & 8.05 & 2.74 & 13.18 & $2.91 E+03$ & $7.29 \mathrm{E}+06$ & 1.79 \\
\hline
\end{tabular}

MHDP reported in Table 2 was used to compute a column height of $15.4 \mathrm{~km}$, which is similar to that reported by eyewitness observation (SERNAGEOMIN, 2015b,c). Similarly, the values calculated for the column heights associated with layers A and D are respectively 10.2$12.3 \mathrm{~km}$ and $11.8-13.2 \mathrm{~km}$.

When the average total erupted mass (TM, $\mathrm{kg}$ ) of units B-C is considered, and the column height equation of Sparks et al. (1997) is solved for mass discharge rate (MDR), we can calculate the duration of the eruption as TM/MDR, which yields an estimate of $4.67 \mathrm{~h}$ (Table 4 ). In the same way, the eruption durations for layers $A$ and $D$ are estimated to be $0.54-1.03 \mathrm{~h}$ and $1.79-2.76 \mathrm{~h}$, respectively (Table 4 ). In this context, the full eruption duration (all layers, both pulses) is calculated between 7 and $11 \mathrm{~h}$. Official reports indicate that the first pulse lasted $1.5 \mathrm{~h}$ and the second $6 \mathrm{~h}$, so the total duration was $7.5 \mathrm{~h}$. This allows us to discriminate among these calculations and to consider that the most plausible eruptive scenario corresponds to columns varying from 12 to $15.4 \mathrm{~km}$, with a total duration of the eruption of about $7 \mathrm{~h}$ (Table 4). Our total mass and MDR values can be used to estimate the magnitude and intensity of each unit, following the approach of Pyle (2000). Individually, magnitude varies from 3.0 to 4.14 , and it is 4.45 for the total deposit (Table 5).

\section{Discussion}

\subsection{Eruption dynamics}

In this study we have divided the stratigraphic sequence of the 2223 April 2015 eruption into several layers, which can be individually sampled and measured only in the proximal-medial deposits. In distal areas, these layers could not be measured, sampled or correlated with accuracy. Because of this, our stratigraphic characterization of layers is based on the study of proximal to medial outcrops. Size grading is most commonly interpreted in terms of steadiness of the eruption column, but can also be influenced by wind shifts and inclination of the column or jet (Houghton and Carey, 2015). The size grading shown by our tephra layers lead to the interpretation that layer A represents the start of the eruption, with a progressive increase of intensity, followed by a paroxysm of activity at the A-B transition, which was followed by a sustained eruption at layer $C$ and waning of the eruption represented by the non-graded layer D (Fig. 8). According to the results obtained with the largest clast data, an average column height of $\sim 15.4 \mathrm{~km}$ has been estimated for layers B and C, which aligns with observations given in official reports (SERNAGEOMIN, 2015b,c). Our calculations of column height give smaller values compared to satellite imagery that indicate a column of $16-18 \mathrm{~km}$ in height (CiMMS, 2015). An intrinsic uncertainty of at least $\pm 20 \%$ has been reported for the Carey and Sparks (1986) method for column height estimation (Biass and Bonadonna, 2011); therefore, we consider the maximum column height to have been in the range $15.4 \pm 3.08 \mathrm{~km}$ for layers B and C. In any case, the largest values of column height in $B$ and $C$ suggest the occurrence of two strong energy episodes. This suggests difference in wind direction that could be related to variation in the meteorological conditions or a change in the column height.

Additionally, layers B and $C$ show a very similar deposit distribution on land (Fig. 5D, E), and both the first and second pulse plumes were dispersed in very similar directions according to satellite imagery (Fig. 4). In fact, a similar dynamics of layers B and C may indicate rising of two paroxysmal phases at the end of the eruption onset and during the start of the second pulse on 22 and 23 April 2015 (Fig. 8), respectively. Good agreement is found when the satellite image of the 09.38 GMT on 23 April is compared with the dispersal of layer D.

A sharp distinction in grain size among layers in fallout deposits is commonly interpreted as non-sustained or spasmodic activity (Houghton and Carey, 2015); therefore, the field observations of the 22-23 April tephra deposits imply that the eruption which deposited these layers was likely sustained (Fig. 8), although two distinct pulses deposited the whole sequence. The evident gradual contact seen at medial-distal distance, especially between layers C-D, makes it difficult to delimitate layer thickness. Such contact may be explained in terms of the higher density of the particles of the $\mathrm{D}$ layer plume, which probably fell together with some of the Clayer particles because of the higher settling velocity of the denser particles in the D tephra (Bonadonna et al., 1998). Also, direct observations indicate that there was not a pause between the emission of $C$ and $\mathrm{D}$ tephras, which indicates that the eruption evolved progressively with time, with a decreasing eruptive column height ranging from $\sim 15.4$ to $\sim 12-13 \mathrm{~km}$ (Fig. 8). This is also supported by satellite observations of the plume, which became elongated near the source at 09.38 GMT (Fig. 4F), before detaching from the source at 10.08 GMT on 23 April.

Table 5

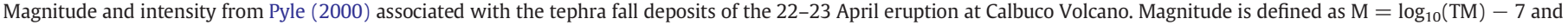
intensity is $\mathrm{I}=\log _{10}(\mathrm{MDR})+3$. The values of TM and MDR are derived from Table 4 .

\begin{tabular}{|c|c|c|c|c|c|}
\hline Mass of the total (proximal-distal) [kg] & A (22 April) & B (22 April) & C (23 April) & D (23 April) & Whole deposit $(A+B+C+D)$ \\
\hline Average & $1.01 \mathrm{E}+10$ & $8.31 \mathrm{E}+10$ & $1.39 \mathrm{E}+11$ & $4.70 \mathrm{E}+10$ & $2.80 \mathrm{E}+11$ \\
\hline Duration [s] & 684 & $4.72 \mathrm{E}+03$ & $6.36 \mathrm{E}+03$ & $1.53 \mathrm{E}+04$ & 27,096 \\
\hline $\operatorname{MDR}[\mathrm{kg} / \mathrm{s}]$ & $1.48 \mathrm{E}+07$ & $1.76 \mathrm{E}+07$ & $2.19 \mathrm{E}+07$ & $3.06 \mathrm{E}+06$ & $1.03 \mathrm{E}+07$ \\
\hline Magnitude & 3.01 & 3.92 & 4.14 & 3.67 & 4.45 \\
\hline Intensity & 10.17 & 10.25 & 10.34 & 9.49 & 10.01 \\
\hline
\end{tabular}


The DF07 site (Table 2) is the most difficult to explain because a thin $(0.5 \mathrm{~cm})$, high-density pumice layer (B1) is observed to interrupt layer $B$. This outcrop is located $13 \mathrm{~km}$ from the vent and at an azimuth of $62^{\circ}$ (Fig. 2D); layer B1 does not appear in other crosswind sections investigated (Fig. 3). In comparison to B1, layer B has a considerable difference in the dispersal axis with an azimuth of $\sim 42^{\circ}$. From these observations, we suggest that B1 was deposited before the end of the first eruptive pulse on 22 April and only in a very narrow strip of land. According to oblique photos from ground-based observers, before the end of the first eruption pulse, a low-altitude $(\sim 2-3 \mathrm{~km}$ acl $)$ secondary plume arose from the vent and was dispersed to $\sim 60^{\circ}$ azimuth (Fig. 8). Some possible explanations for this phenomenon are, for example, an atmospheric stratification transporting denser fragments in a specific altitude level, or more likely the activity of multiple vents emitting different materials simultaneously. Rapid satellite imagery acquisition after the eruption on 25 April (https://www.disasterscharter. org/web/guest/-/volcano-in-ch-20) reveals venting from six craters and field photography show almost two individual lava fountains (Fig. 8).

The total deposit isopach map also provides insight of a secondary thickness maxima observed approximately $150 \mathrm{~km}$ downwind from the vent. This feature was attributed to particle aggregation process in the tephra fall deposits of Mt. Hudson 1991 eruption (Scasso et al., 1994) and Mt. Saint Helens 1980 eruption (Durant et al., 2009). Recently, Watt et al. (2015) reported two possible causes for a secondary thickness maxima at the Cha1 Plinian tephra deposit of Chaitén volcano. These include the formation of liquid pellets driven by rainfall, or more likely an accelerated deposition of particles (100 to $500 \mu \mathrm{m}$ ) influenced by topography of the downwind regime. Our results do not include grain size analysis in that area, but according to satellite observations we suggest that an overlap of the different eruption plumes of each pulse may have influenced the deposition of thicker tephra layers over the $37^{\circ} \mathrm{S}-41^{\circ} \mathrm{S}$ as observed in other eruptions (e.g., Watt et al., 2009), in this case due to a change in wind direction. An investigation on topography-controlled deposition and aggregation of particles have to be object of a detailed study in the future, especially because these tephra secondary thickness maximum regions may have a larger impact for tephra fallout.

The complexity of deposits emplaced by multiple vents and PDCs, possibly produced by several mechanisms (e.g., partial column collapse, lateral jetting), suggest that the stratigraphic sequence may be much more complex close to the vents than we were able to sample (ca. $5 \mathrm{~km}$ ). More sampling in areas close to the vent would be useful for a better reconstruction of proximal stratigraphy and eruptive mechanisms. According to eyewitness observations, the column collapse started at the end of the first pulse (here top of layer B); our observations, however, are based on tephra fall deposits and we did not collect samples for characterizing PDCs. Future investigations should be focused on the stratigraphic correlation between the tephra fall sequence and PDC deposits, in order to achieve a better reconstruction of the explosive eruption dynamics. In addition, detailed petrological and geochemical studies of the erupted material are required for understanding the pre-eruptive conditions of this sudden eruption.

\subsection{Eruption style}

Our volume estimates are not absolute values, because an inherent uncertainty is intrinsically related to the measuring procedure, isopach drawing technique and method of integration (e.g. Bonadonna and Costa, 2012; Andronico et al., 2014; Klawonn et al., 2014; Bonadonna

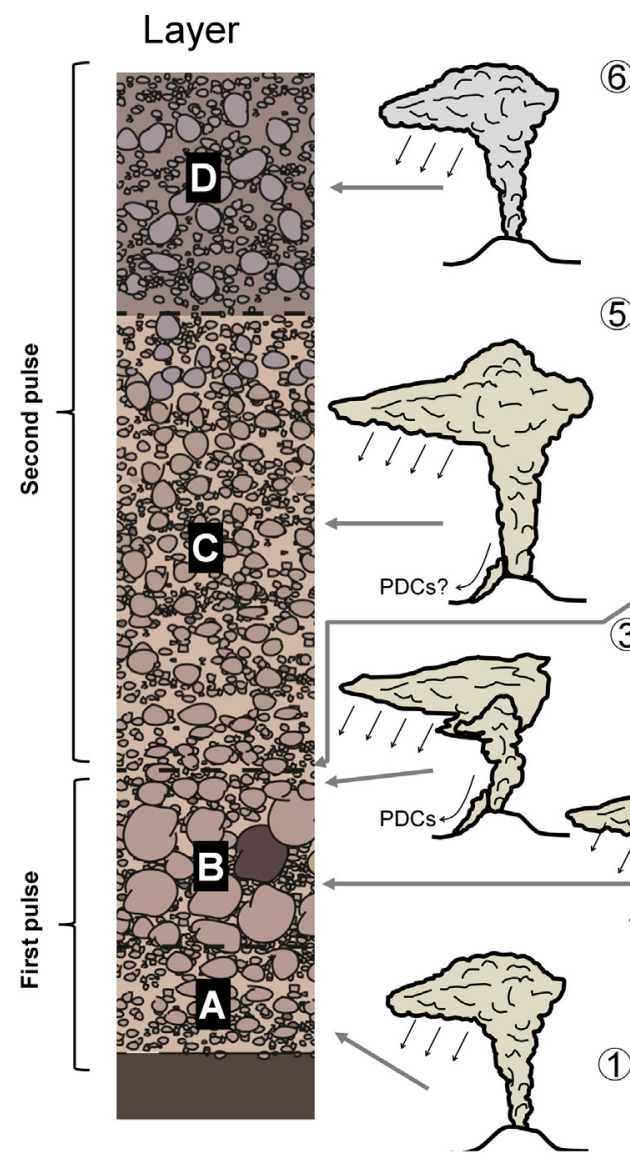

6) End of second pulse: Increase of high-
density pumice. Decrease of the eruption
column to $12-13 \mathrm{~km}$ in height in comparison
to layer C. No evidence of grading
associated to gradual column decreasing
before the end of activity. A sudden end of the eruption is required.

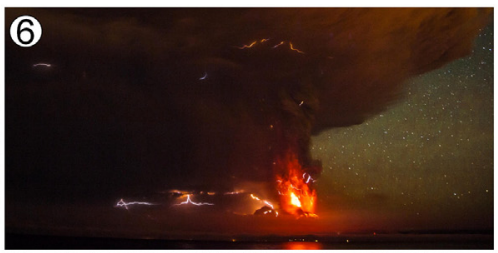

(5) Second Paroxysm: It starts with a column reaching $>15 \mathrm{~km}$ in height. The eruption persists sustained by 4.7-5.9 hours. The layer $C$ is being deposited and the highdensity pumice becomes frequent at the end of this phase. Did the column collapses continued?

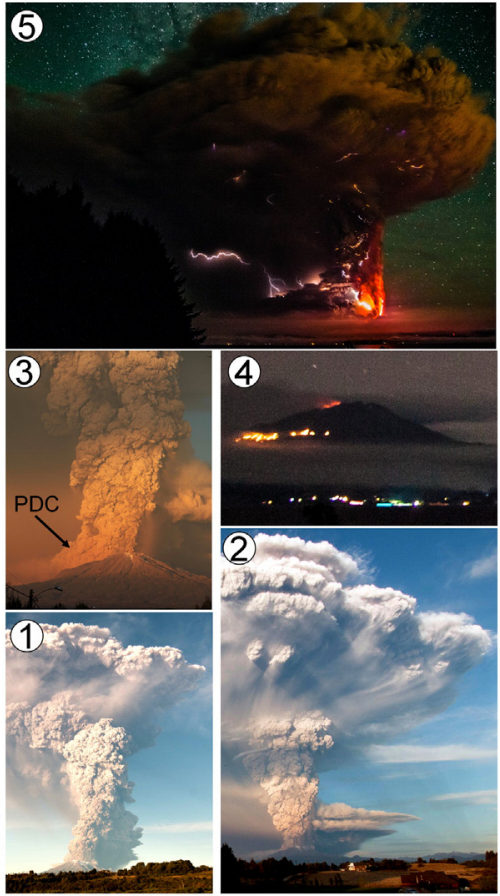

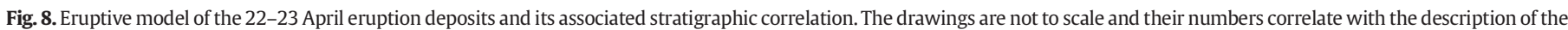
eruption dynamics, and with direct observations to the right of the figure. 
et al., 2015). Layers B, C and D are observed in distal sections, so we assume that the distal deposit is made almost exclusively of these three layers. These thin $(<1 \mathrm{~cm})$ deposits do not allow for an accurate measurement of single layers. Our best estimate is that layer A accounts for $\sim 11 \%$ of the total volume, B contributes 27.4\%, C 46\% and D 15.6\%. Using these volume estimates, weighting them by the proportion of each layer and the total volumes calculated including distal data, we obtain the volume equivalences for each model and layer of the whole deposit (proximal to distal) (Fig. 9A). Therefore, the first pulse released $\sim 38 \%$ and the second pulse $\sim 62 \%$ of the total volume. Acknowledging propagation of uncertainty, we refer to volume estimates in terms of ranges derived using different methods. Using our values and the volumes erupted based on 65 sample sites spanning proximal to distal sites, we calculate a cumulative trend in time based on each model (Fig. 9B). In terms of intensity, the layers range from 9.49 (unit D) to 10.34 (unit C), and the total deposit is 10.01 (Table 5). This implies that the Calbuco eruption can be classified as VEI 4. According to the conventional classification scheme applied by Alfano et al. (2011) for the 2008-2009 Chaitén volcano eruption, the total deposit of this eruption plots in the field of SubPlinian eruptions (Fig. 9C). This explosive eruptive behavior is similar to historic eruptions at Calbuco (for example in $1893-95 ; 1917 ; 1929 ; 1961)$, with the exception that the present eruption did not produce lava flows or lava domes. Furthermore, the tephra fall volume discharged by the 2015 eruption is similar to that calculated for the eruption of $1961\left(\sim 0.2 \mathrm{~km}^{3}\right.$; Romero et al., 2013). The ejecta basaltic andesitic composition is also very similar to that reported for previous eruptions in 1917, 1961 and 1971 by Sellés and Moreno
(2011). If we consider that the historical records of Calbuco eruptions are dependable from the 1906 eruption (due to the human activity in the area), nine eruptions have occurred in the last 109 years (including 2015). Thus, the eruption rate is approximately 0.083 eruptions/year and the repose time (1/eruption rate) is near to 12 years. Even if the pre-eruptive seismic swarm started only a few hours prior the eruption onset (SERNAGEOMIN, 2015a) and no pre-eruptive deformation was observed (Delgado et al., 2015), the steady increase in seismicity three months before the eruption (Valderrama et al., 2015) would be sufficient for providing an early advice of volcanic unrest. Calbuco Volcano is one of the most hazardous volcanoes of southern Andes. As a consequence of that, tephra fall hazard is a topic that needs to be addressed for southern Andean communities like it has been demonstrated by this eruption and other recent volcanic activity in this region (e.g. Wilson et al., 2010; Alfano et al., 2011; Araya, 2015; Elissondo et al., 2015).

\section{Conclusions}

The 22-23 April 2015 basaltic andesitic ( $~ 55$ wt.\% of $\mathrm{SiO}_{2}$ ) eruption of Calbuco Volcano started suddenly with a high-intensity explosive phase with very little warning to the neighboring communities. Two main subPlinian pulses separated by a few hours deposited five tephra fall layers, mostly northeast of the volcano. The first pulse started on April 22 at 21.05 GMT with a column $\sim 15 \mathrm{~km}$ high above the crater and deposited layers A, B and B1. Layer B1 is interpreted as sedimentation of a secondary low-altitude plume. Another eruption pulse
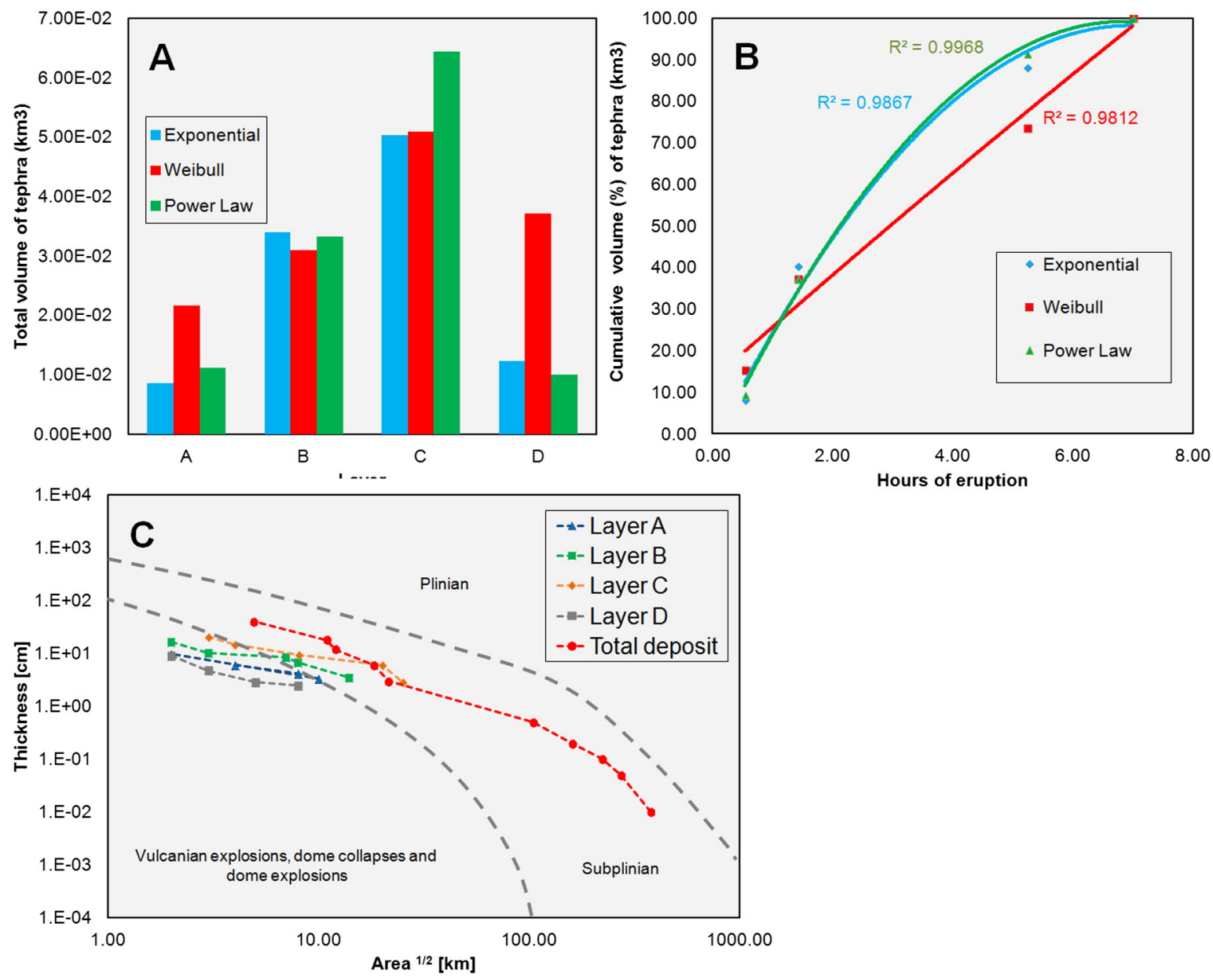

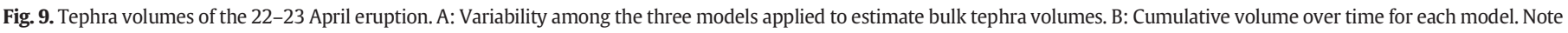

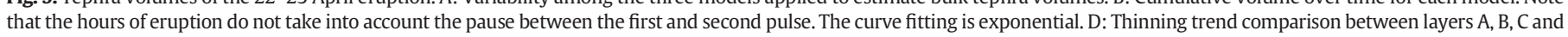
D. Classification scheme modified from Alfano et al. (2011). 
occurred on 23 April at 04.09 GMT with a column $>15 \mathrm{~km}$ in height, and deposited layers $C$ and $D$. The proximal stratigraphy reveals four of the five units, and most of the ejected products range from coarse lapilli to bomb-size. The deposits thin and particle diameter decreases with distance along the downwind axis, with the exception of an outsider region in Argentina (Collón Cura and Piedra del Águila), which is likely the result of variations in the wind pattern. These distal deposits consist of 2 or 3 layers ( sometimes C-D or B, C and D) when they can be discriminated, but only a single ash trace is observed in most of the distal sampling localities in Patagonia Argentina and Southern Chile. The total volume of the eruption is estimated to be $0.28 \mathrm{~km}^{3}$ of bulk tephra, which is equivalent to $0.11-0.13 \mathrm{~km}^{3}$ DRE. The first phase released $~ 38 \%$ of the total volume with layer $\mathrm{C}$ accounting for $~ 46 \%$ of the total released tephra. Layer D accounted for $16 \%$ of the deposited tephra. The magnitude of the eruptions producing each layer ranged between 3.0 and 4.14 and the intensity from 9.49 to 10.34 , while the whole eruption is 4.45 and 10.01 in magnitude and intensity, respectively. This was a VEI 4 eruption.

\section{Acknowledgements}

This work, was supported by the ERC Consolidator Grant 612776 CHRONOS (D. Pergini) and the ERC Consolidator Grant 279802 CO2_VOLC (M.Burton). The Authors acknowledge the editor L. Wilson and the two reviewers S. Watt and M. A. Di Vito for whose revisions greatly improved the manuscript. We would like to thank F. J. Swanson for constructive comments on the manuscript. Support from I. Boroni, Hermes G., A. Martinez, I. Silva, H. Moyano, R. Garrido, V. Astete and M. Lincopi was essential to obtain near real-time, geo-referenced data of tephra fall in distal areas. Photos from Roger Smith, C. Valenzuela, E. Minte, C. Barría, K. Horning and D. Spatafore helped to reconstruct the eruption chronology. Romero, Morgavi and Arzilli are grateful to Mr. F. Mancilla and J. Valenzuela (TerraSur Ensenada Corp.) for their assistance during fieldwork.

\section{References}

Alfano, F., Bonadonna, C., Volentik, A.C.M., Connor, C.B., Watt, S.F.L., Pyle, D.M., Connor, L.J., 2011. Tephra stratigraphy and eruptive volume of the May, 2008, Chaitén eruption, Chile. Bull. Volcanol. 73, 613-630.

Andronico, D., Scollo, S., Cristaldi, A., Lo Castro, M.D., 2014. Representivity of incompletely sampled fall deposits in estimating eruption source parameters: a test using the 1213 January 2011 lava fountain deposit from Mt. Etna volcano, Italy. Bull. Volcanol. 76, 861. http://dx.doi.org/10.1007/s00445-014-0861-3.

Araya, O., 2015. Erupciones volcánicas. Efectos sobre la ganadería. Ediciones UACH, Valdivia, Chile.

Astudillo, V., Bertin, L., Bertin, D., 2015. Características Texturales Y composicionales de La Tefra Del Ciclo Eruptivo de Abril-Mayo de 2015 en El volcán Calbuco. Congreso Geológico Chileno, No. XIV, La Serena, Chile.

Biass, S., Bonadonna, C., 2011. A quantitative uncertainty assessment of eruptive parameters derived from tephra deposits: the example of two large eruptions of Cotopaxi volcano, Ecuador. Bull. Volcanol. 73, 73-90.

Blott, S.J., Pye, K., 2001. Gradisat: a grain size distribution and statistics package for the analysis of unconsolidated sediments. Earth Surf. Process. Landf. 26, 1237-1248. http://dx.doi.org/10.1002/esp.261.

Bonadonna, C., Costa, A., 2012. Estimating the volume of tephra deposits: a new simple strategy. Geology 40 (5), 415-418. http://dx.doi.org/10.1130/G32769.1.

Bonadonna, C., Houghton, B.F., 2005. Total grainsize distribution and volume of tephra fall deposits. Bull. Volcanol. 67, 441-456.

Bonadonna, C., Biass, S., Costa, A., 2015. Physical characterizationof explosive volcanic eruptions based on tephra deposits: propagation of uncertainties and sensitivity analysis. J. Volcanol. Geotherm. Res. http://dx.doi.org/10.1016/j.jvolgeores.2015.03.009.

Bonadonna, C., Cioni, R., Pistolesi, M., Connor, C.B., Scollo, S., Pioli, L., Rosi, M., 2013. Determination of the largest clast sizes of tephra deposits for the characterization of explosive eruptions: a study of the IAVCEI commission on tephra hazards modeling. Bull. Volcanol. 75 (1), 680.

Bonadonna, C., Ernst, G.G.J., Sparks, R.S.J., 1998. Thickness variations and volume estimates of tephra fall deposits: the importance of particle Reynolds number. J. Volcanol. Geotherm. Res. 81 (3), 173-187.

Carey, S., Sparks, R.S.J., 1986. Quantitative models of the fallout and dispersal of tephra from volcanic eruption columns. Bull. Volcanol. 48 (2-3), 109-125. http://dx.doi. org/10.1007/BF01046546.
Castruccio, A., Clavero, J., Rivera, A., 2010. Comparative study of lahars generated by the 1961 and 1971 eruptions of Calbuco and Villarrica volcanoes, Southern Andes of Chile. J. Volcanol. Geotherm. Res. 190 (3-4), 297-311.

CiMMS Satelite Blog. Accessed on July 03, 2015. http://cimss.ssec.wisc.edu/goes/blog/ archives/date/2015/04/23

Clavero, J., Godoy, E., Arancibia, G., Rojas, C., Moreno, H., 2008. Multiple Holocene Sector Collapses at Calbuco Volcano, Southern Andes. Abstracts, Poster Session III, IAVCE General Assembly, Reykjavik, Iceland, p. 41.

Daga, R., Guevara, S., Poiré, D.G., Arribére, M., 2014. Characterization of tephras dispersed by the recent eruptions of volcanoes calbuco (1961), Chaitén (2008) and Cordón caulle complex (1960 and 2011), in Northern Patagonia. J. S. Am. Earth Sci. 49 (2014), 1-14.

Delgado, F., Pritchard, M.E., Ebmeier, S., Biggs, J., Arnold, D., González, P., Poland, M. Zoffoli, S., Córdova, L., Lara, L.E., 2015. The CEOS pilot project, satellite volcano monitoring in Latin America and new InSAR ground deformation results at Llaima, Villarica and Calbuco volcanoes. Congreso Geológico Chileno, No. XIV, La Serena, Chile.

Durant, A.J., Rose, W.I., Sarna-Wojcicki, A.M., Carey, S., Volentik, A.C.M., 2009 Hydrometeor-enhanced tephra sedimentation: constraints from the 18 May, 1980 eruption of Mount St. Helens. J. Geophys. Res. 114, B03204.

Elissondo, M., Baumann, V., Bonadonna, C., Pistolesi, M., Cioni, R., Bertagnini, A., Biass, S. Herrero, J.C., Gonzalez, R., 2015. Chronology and impact of the 2011 PuyehueCordón Caulle eruption, Chile. Nat. Hazards Earth Syst. Sci. Discuss. http://dx.doi. org/10.5194/nhessd-3-5383-2015.

Fisher, O., 1893. Erupción del volcán Calbuco. Anales de la Universidad de Chile LXXXV. Imprenta Nacional, Santiago, Chile, pp. 197-204.

Fisher, R.V., Schmincke, H.U., 1984. Pyroclastic rocks. Springer, Berlin (472 pp., doi, 10, 978-3).

Folk, R.L., Ward, W.C., 1957. Brazos river bar: a study in the significance of grain size parameters. J. Sediment. Petrol. 27, 3-26.

González, F., 1898. Exploraciones hidrográficas de la cañonera Pilcomayo en la costa sur de la república i Chiloé en 1893-94. Anuario hidrográfico de la Marina de Chile. Imprenta i encuadernación Barcelona, Año 21. Imprenta i encuadernación Barcelona, Santiago, Chile, pp. 45-118.

González-Ferrán, O., 1995. Volcanes de Chile. Instituto Geográfico militar, Santiago, Chile.

Held, E., 1993. familia Held: antecedentes históricos. Radicación de Gottfried Held y familia en la colonia del lago Llanquihue. Antepasados en Alemania y descendientes en Chile. Claus von Plate, Santiago (314 pp.).

Houghton, B., Carey, R.J., 2015. Pyroclastic fall deposits. In: Sigurdsson, H., Houghton, B. McNutt, S., Rymer, H., Stix, J. (Eds.), The encyclopedia of volcanoes. Elsevier.

Kinzel, E., Horn, B., 1983. Puerto Varas, 130 años de Historia, 1852-1983. Imprenta y Librería Horn, Puerto Varas, Chile (414 pp.).

Klawonn, M., Houghton, B.F., Swanson, D.A., Fagents, S.A., Wessel, P., Wolfe, C.J., 2014 From field data to volumes: costraining uncertainties in pyroclastic eruption parameters. Bull. Volcanol. 76, 893.

Klohn, E., 1963. The February 1961 eruption of Calbuco Volcano. Bull. Seismol. Soc. Am. 53 (6), 1435-1963.

Lahsen, A., Moreno, H., Varela, J., Munizaga, F., López, L., 1985. Proyecto Canutillar: geología y riesgo volcánico del volcán Calbuco y centros eruptivos menores. Universidad de Chile, ENDESA (215 pp.).

López-Escobar, L., Parada, M.A., Hickey-Vargas, R., Frey, F.A., Kempton, P.D., Moreno, H., 1995. Calbuco Volcano and minor eruptive center distributed along the Liquiñe Ofqui Fault Zone, Chile $-41^{\circ}-42^{\circ}$ s-: contrasting origin of andesitic and basaltic magma in the Southern Volcanic Zone of the Andes. Contrib. Mineral. Petrol. 119, 345-361.

Martin, C., 1895. La erupción del volcán Calbuco. Anales de la Universidad de Chile, Imprenta Cervantes, Santiago, pp. 161-193.

Moreno, H., Naranjo, J.A., 2004. Calbuco volcano historic block-and-ash and pyroclastic flows: increasing threatening on surrounding communities, Southern Andes $41.5^{\circ} \mathrm{S}$ IAVCEI General Assembly, Pucón, Chile, November 2004 vol. 4.

Moreno, H., Naranjo, J.A., Clavero, J., 2006. Generación de lahares calientes en el volcánCalbuco, Andes del Sur de Chile $\left(41,3^{\circ} \mathrm{S}\right)$. XI Congreso Geológico Chileno, Antofagasta, Chile (CD).

Newhall, C., Self, S., 1982. The volcanic explosivity index (VEI): An estimate of explosive magnitude for historical volcanism. J. Geophys. Res. 87, 1231-1238.

Petit-Breuilh, M.E., 1999. Cronología eruptiva histórica de los volcanes Osorno y Calbuco, Andes del Sur $-41^{\circ}-41^{\circ} 30^{\prime}$ S. SERNAGEOMIN, Boletín (n.53) (46 pp.).

Petit-Breuilh, M.E., Moreno, H., 1997. La erupción de 1893-1895 del Volcán Calbuco $-41.3^{\circ} \mathrm{S}-\mathrm{y}$ sus efectos ambientales. En Congreso Geológico Chileno, 8., Antofagasta, Chile, 13-17 Octubre 1997, pp. 780-784.

Pöhlmann, R., 1893. Estudio microscópico de algunas cenizas volcánicas del Calbuco provenientes de las erupciones del año 1893. Anales de La Universidad de Chile LXXXV. Imprenta Nacional, Santiago, pp. 204-217.

Pyle, D.M., 1989. The Thickness, Volume and Grainsize of Tephra Fall Deposits. Bull. Volcanol. 51, 1-15

Pyle, D.M., 1995. Assessment of the minimum volume of tephra fall deposits. J. Volcanol. Geotherm. Res. 69, 379-382. http://dx.doi.org/10.1016/0377-0273(95)00038-0.

Pyle, D.M., 2000. Sizes of Volcanic Eruption. Encyclopedia of Volcanoes. Academy Press. Part II, San Diego California, pp. 263-269.

Romero, J.E., Viramonte, J.G., Scasso, R.A., 2013. Indirect tephra volume estimations using theoretical models for some Chilean historical volcanic eruptions with sustained columns. Boll. Geofis. Teor. Appl. 54 (Supplement 2), 194-197.

Scasso, R.A., Corbella, H., Tiberi, P., 1994. Sedimentological analysis of the tephra from the 12-15 august 1991 eruption of Hudson volcano. Bull. Volcanol. 56, 121-132.

Sellés, D., Moreno, H. 2011. Geología del volcán Calbuco. Carta Geológica de Chile, Serie Geología Básica No. 130, escala 1:50.000.

SERNAGEOMIN, 2015a. Reporte Especial de Actividad Volcánica (REAV) Región de los Lagos. (REAV) Año 2015 Abril 22 (20:45 HL). 
SERNAGEOMIN, 2015b. Reporte Especial de Actividad Volcánica (REAV) Región de los Lagos. Año 2015 Abril 22 (22:30 HL).

SERNAGEOMIN, 2015c. Reporte Especial de Actividad Volcánica (REAV) Región de los Lagos. Año 2015 Abril 23 (10:30 HL).

Sparks, R.S.J., Bursik, M.I., Carey, S.N., Gilbert, J.S., Glaze, L.S., Sigurdsson, H., Woods, A.W. 1997. Volcanic Plumes. John Wiley and Sons, New York (574 pp.).

Steffen, H., 1909. Viajes de esploración y estudio de la Patagonia occidental 1892-1902. Imprenta Cervantes, Santiago (409 pp.).

Steffen, H., 1944. Patagonia occidental. Las cordilleras patagónicas y sus regiones circundantes. Ediciones de la Universidad de Chile, Santiago (333 pp.).

Stern, C., Moreno, H., Lopez-Escobar, L., Clavero, J., Lara, L., Naranjo, J., Parada, M., Skewes, M., 2007. Chilean Volcanoes. In: Moreno, T., Gibbons, W. (Eds.), The Geology of Chile. Geological Society of London, London, pp. 149-180.

Valderrama, O., Franco, L., Gil-Cruz, F., 2015. Erupción intempestiva del volcán Calbuco, Abril 2015. Congreso Geológico Chileno, No. XIV, La Serena, Chile.
Watt, S., Gilbert, J., Folch, A., Phillips, J., Cai, X., 2015. An example of enhanced tephra fallout driven by topographically-induced atmospheric turbulence. Bull. Volcanol. 77 (35). http://dx.doi.org/10.1007/s00445-015-0927-x.

Watt, S.F.L., Pyle, D.M., Mather, T.A., Martin, R.S., Matthews, N.E., 2009. Fallout and distribution of volcanic ash over Argentina following the May 2008 explosive eruption of Chaitén, Chile. J. Geophys. Res. Solid Earth 114 (11), B04207. http://dx.doi.org/10. 1029/2008jb006219.

Watt, S.F.L Pyle, D.M. Naranjo, J.A Rosqvist, G, Mella, M, Mather, T A Moreno, H., 2011. Holocene tephrochronology of the hualaihue region (Andean southern volcanic zone, $\sim 42^{\circ}$ S), Southern Chile. Quat. Int. 246, 324-343.

Whitney, D.L., Evans, B.W., 2010. Abbreviations for names of rock-forming minerals. Am. Mineral. 95 (1), 185.

Wilson, T., Cole, J., Cronin, S., Stewart, C., Johnston, D., 2010. Impacts on agriculture following the 1991 eruption of Vulcan Hudson, Patagonia: lessons for recovery. Nat. Hazards. http://dx.doi.org/10.1007/s11069-010-9604-8. 